\title{
Altered Expression of the Cell Cycle Regulatory Molecules pRb, p53 and MDM2 Exert a Synergetic Effect on Tumor Growth and Chromosomal Instability in Non-small Cell Lung Carcinomas (NSCLCs)
}

\author{
V. G. Gorgoulis 1,2, P. Zacharatos ${ }^{1,2}$, A. Kotsinas ${ }^{1,2}$, G. Mariatos ${ }^{1}$, T. Liloglou2, \\ T. Vogiatzi ${ }^{1}$, P. Foukas ${ }^{1}$, G. Rassidakis', G. Garinis' ${ }^{1}$, T. Ioannides ${ }^{1}$, \\ V. Zoumpourlis', J. Bramis', P. O. Michail' ${ }^{3}$, P. J. Asimacopoulos ${ }^{4}$, J. K. Field ${ }^{2}$, \\ and Ch. Kittas ${ }^{1}$ \\ ${ }^{1}$ Department of Histology and Embryology, Medical School, University of Athens, \\ Greece \\ ${ }^{2}$ Roy Castle, International Institute for Lung Cancer Research, Liverpool, U.K. \\ ${ }^{3}$ First Department of Surgery, Laiko Hospital, ${ }^{4}$ Department of Cardiac Surgery, \\ Medical School, University of Athens, Greece
}

Communicated by A. Papavassiliou. Accepted November 22, 1999.

\begin{abstract}
Background: Recent in vitro studies provide evidence that the cell cycle molecules pRb, p53 and MDM2 form a tightly regulated protein network. In this study, we examined the relationship of this protein network in a series of non-small cell lung carcinomas (NSCLCs), with the kinetic parameters, including proliferative activity or proliferation index (PI) and apoptotic index (AI), and ploidy status of the tumors.

Material and Methods: A total of 87 NSCLCs were examined using immunohistochemical and molecular methods in order to estimate the status of the pRb-p53-MDM2 network. The kinetic parameters and the ploidy status of the tumors were assessed by in situ assays. The possible associations between alterations of the network, kinetic parameters and ploidy status of the carcinomas were assessed with a series of statistical methods.

Results: Aberrant expression of pRb (Ab) and overexpression of p53 (P) and MDM2 (P) proteins were observed in $39 \%, 57 \%$, and $68 \%$ of the carcinomas, respectively. The comprehensive analysis revealed that concurrent alterations in all three cell cycle regulatory molecules were the most frequent pattern, $\mathrm{pRb}(\mathrm{Ab}) / \mathrm{p} 53(\mathrm{P}) / \mathrm{MDM} 2(\mathrm{P})$; this "full abnormal" phenotype represented approximately $27 \%$ of the cases. This immunoprofile obtained the highest
\end{abstract}

PI/AI value; whereas, the "normal" phenotype was the lowest one $(p=0.004)$. Furthermore, the pattern $\mathrm{pRb}(\mathrm{Ab}) / \mathrm{p} 53(\mathrm{P}) / \mathrm{MDM} 2(\mathrm{P})$ acquired the highest PI $(p<0.001)$ and lowest AI $(p<0.001)$ scores. Interestingly, the groups of carcinomas with impaired expression of one or two molecules attained PI/AI ratio values clustered in a narrow range placed in the middle of the scores exhibited by the "normal" and "full abnormal" phenotypes. These tumors had significantly lower AI, but similar PI values, compared with those noticed in the normal pattern. In addition, it was observed that the $\mathrm{pRb}(\mathrm{Ab}) / \mathrm{p} 53(\mathrm{P}) /$ MDM2(P) phenotype was also significantly associated with aneuploidy $(p=0.002)$ and a tendency was observed when the expression of two components was altered ( $p=0.055)$.

Conclusions: Our findings suggest that simultaneous deregulation of all members of the pRb-p53MDM2 network confers an additive effect on tumor growth. The apoptotic pathway seems to be more susceptible to its defects than the cell proliferation machinery. The findings of the ploidy analysis, which are in parallel with those regarding the proliferative activity and the apoptotic rate study, further support the concept that these molecules constitute a tightly regulated network participating in cell cycle control and chromosomal stability. 


\section{Introduction}

Physiological cells possess protective mechanisms that sense stress and oncogenic signals. When sensing stress, the cells trigger countermeasures in order to limit the deleterious effect (1); whereas, with oncogenic signals they will react by controlling proliferative activity (2). The dominant factors in this response are the p53 and pRb tumor-suppressor proteins. Alterations in these molecules represent two of the most common phenomena in human malignancies $(3,4)$.

The $\mathrm{pRb}$ protein is a $105 \mathrm{kDa}$ nuclear phosphoprotein, which belongs to the "pocket" protein family that also includes p107 and p130. The main function of $\mathrm{pRb}$ is to control cell cycle progression through the Gl phase. This occurs when pRb interacts in its dephosphorylated form with a multitude of cellular factors that regulate gene expression at various levels $(5,6)$. Gradual phosphorylation of pRb, catalyzed by cyclin-dependent kinases (CDKs), inactivates its growth suppressive activity; whereas, members of the CDK inhibitor families control this process, thus, forming a tightly guided pathway $(5,7)$. Another important but paradoxical function, for an oncosuppressor protein like $p R b$, is that lack of its activity not only leads to apoptosis, but restoration of functional pRb directly inhibits its activity (8). The wild-type (wt) p53 protein, on the other hand, is a vital G1/S and G2/M "checkpoint" factor that monitors DNA-damage, as well as other stress signals, inducing either cell cycle arrest or apoptosis (9). The activities of p53 are mainly governed by its downstream effector MDM2. The MDM2 gene is directly activated by p53 and expresses its product, which interacts with p53 forming a regulatory feedback loop (9). The assembled MDM2-p53 complex then targets $\mathrm{p} 53$ for ubiquitin-mediated proteolysis, thus, reducing its levels $(10,11)$. At first sight, the regulation of the p53 and pRb pathways appears to be distinctly different, with p2 $1^{\text {WAF1/Cip } 1}$ being the mere indirect link between them. The WAF1/Cipl gene is a downstream target of $\mathrm{p} 53$, encoding the $\mathrm{p} 21^{\mathrm{WAF} 1 / \mathrm{Cip} 1}$ CDK2 inhibitor, hence controlling the phosphorylation status of pRb (9). However, a re-

Address correspondence and reprint requests to: V. G. Gorgoulis, Antaiou 53, Lamprini, Ano Patissia, Athens, Greece, GR-11146, Phone: ++30-1-2922143;

Fax: ++30-1-7790353; E-mail: histoclub@ath.forthnet.gr cent report demonstrated that the $\mathrm{C}$ pocket domain of pRb (residues 792-928) binds to the C-terminal domain (residues 273-321) of the MDM2 protein, leaving its p53 binding domain free, which lies within the $\mathrm{N}$-terminal region (Fig. 1) (12). Furthermore, another study showed that binding of $\mathrm{pRb}$ to MDM2 inhibits the anti-apoptotic function of MDM2 by preventing the MDM2-dependent degradation of p53 (13). This close interaction between the pRb and p53 pathways, via MDM2, reveals clearly that these major cell cycle regulatory routes actually represent parts of the same network. The intriguing point in this relationship is that two classical oncosuppressors are associated with the same protein, which has been shown to act as an oncoprotein $(14,15)$. The $M D M 2$ gene seems to exert its tumorigenic effects by two mechanisms: overexpression $(14,15)$ and production of alternative splice variants, which add novel oncogenic properties to the cell $(16,17)$. Deregulated expression of $M D M 2$ has been found in various tumors, including sarcomas (18), glioblastomas (19), breast carcinomas (20), urothelial cancers (21), lung carcinomas (22-25) and hematological malignancies (26). Nevertheless, a recent study showed that the MDM2 protein has the ability to inhibit cell cycle progression in a p53independent manner, creating a complicated picture of its role in cell cycle regulation (27). This finding, together with those mentioned above, point out the need to examine the status of the pRb-MDM2-p53 pathway in human malignancies and the consequences of its defects on tumor kinetics.

Another factor that should be considered in association with these proteins is chromosomal instability (CIN). CIN occurs in most human malignancies and reflects gains or losses of segments or whole chromosomes, and leads to an abnormal chromosomal quantity (aneuploidy) (28). The mechanism that underlies this common cancerous phenomenon is just beginning to be investigated and involves alterations of genes implicated in replication, chromosome condensation and segregation, as well as inactivation of "checkpoint" genes that monitor DNA-damage and proper assemblage of the mitotic spindle apparatus (29). It is reasonable to assume that altered expression of a checkpoint protein, like p53, due to mutations or deregulated control, will participate in such a procedure. Although several reports support this assumption (30-32), others show that loss 


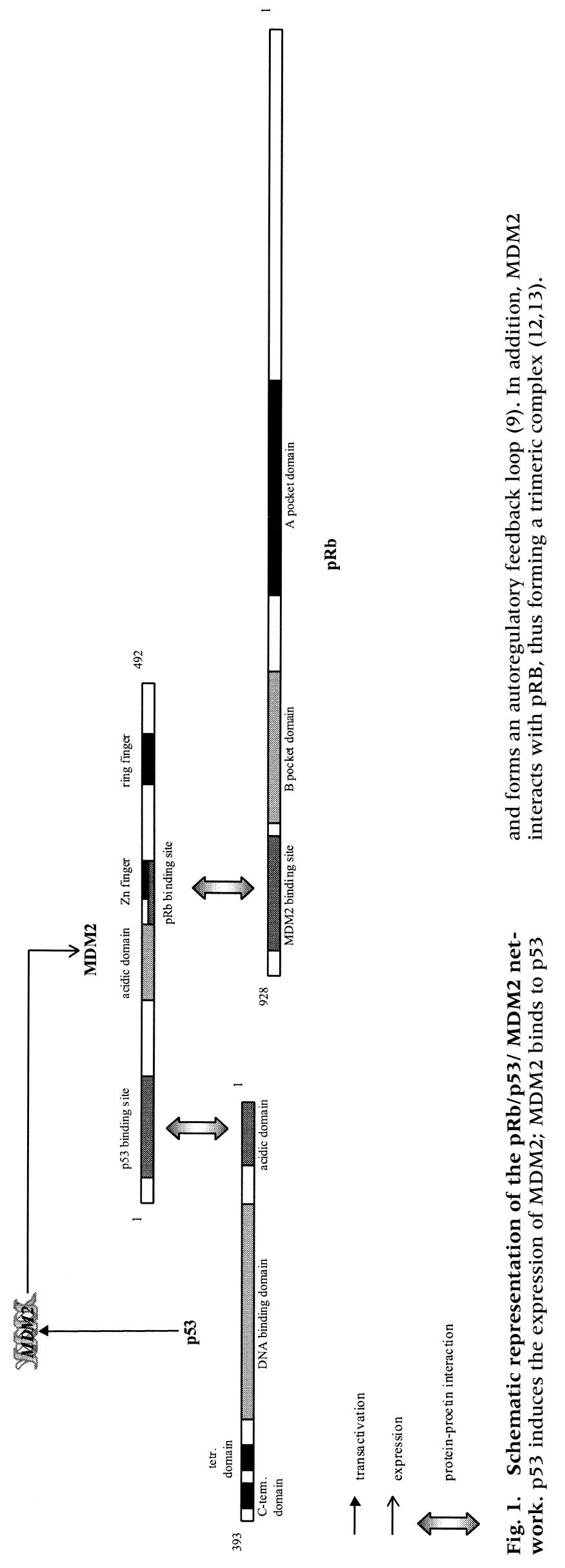


of wt p53 does not abolish the mitotic spindle checkpoint $(33,34)$.

Recently, we analyzed the pl6/pRb/p53/ MDM2 network in a series of NSCLCs and found that concurrent abnormalities of pRb, p53 and MDM2 occurred in approximately $30 \%$ of the tumors examined, representing the most frequent expression pattern (24). The apparent involvement of this trimeric network in tumor progression led us to investigate, in an extended NSCLC database (24), its relationship first with the kinetic parameters of proliferation and apoptosis, which actually determine the growth rate of a tumor (35), and second with the ploidy status of the carcinomas.

\section{Materials and Methods}

\section{Tissue Samples}

A total of 87 NSCLCs and adjacent normal lung tissues were obtained from surgically treated patients (mean age: 63.4 years). For 70 tumor samples, snap-frozen samples in liquid nitrogen, stored at $-70^{\circ} \mathrm{C}$, and formalin-fixed and paraffin-embedded (FFPE) material was available. For the remaining 17 samples, only FFPE material was accessible. The patients had not undergone any chemotherapy or radiotherapy prior to surgical resection, thus, avoiding up- or down-regulation of $\mathrm{pRb}$ and $\mathrm{p} 53$ proteins due to DNA damage $(9,36)$. The material comprised 41 adenocarcinomas (AdCs), 41 squamous cell carcinomas (SqCs) and 5 undifferentiated large cell carcinomas (ULs). Tumors were classified according to the World Health Organization criteria and TNM system (37). Clinicopathological features of the patients are presented in Table 1.

\section{Immunohistochemistry (IHC)}

ANTIBOdies. For immunohistochemical analysis the following antibodies were used:

- LM95.1.

$\Delta$ Class: Immunoglobulin G (IgG)

$\Delta$ mouse monoclonal

$\Delta$ epitope: $\mathrm{pRb}$

$\Delta$ Calbiochem, Biodynamics, Greece

- DO7

$\Delta$ Class: IgG2b

$\Delta$ mouse monoclonal

$\Delta$ epitope: residues $1-45$ of $\mathrm{p} 53$

$\Delta$ Dako, Kalifronas, Greece

\section{- SMP14}

$\Delta$ Class: IgGl

$\Delta$ mouse monoclonal

$\Delta$ epitope: residues 154-167 of MDM2

$\Delta$ Santa Cruz, Bioanalytica, Greece)

\section{- MIB-1}

$\Delta$ Class: IgGl

$\Delta$ mouse monoclonal

$\Delta$ epitope: Ki-67 nuclear antigen

$\Delta$ Oncogene Science, Biodynamics, Greece.

METHOD. Immunohistochemistry was performed according to the indirect streptavidinbiotin-hyperoxidase method, as previously described (24).

CONTROLs. Lung carcinoma specimens from our previous study (24), with well characterized pRb, p53 and MDM2 status, were used as controls for corresponding protein reactivity. Furthermore, in each set of immunoreactions the corresponding IgG fraction of unrelated specificity was used as negative control for the method.

EVALUATION. For scoring pRb, p53, MDM2 and Ki67 expression, we used previously published criteria $(38,24)$.

(a) pRb: Cytoplasmic reactivity was disregarded and only nuclear staining above any cytoplasmic background was considered as evidence of protein expression. The samples were divided into two categories: normal (No), in which more than $90 \%$ of the tumor nuclei were stained, and abnormal (Ab), when there was absence of nuclear staining in a portion of (heterogeneous) or in the entire (homogeneous) tumor section. In addition, admixed non-neoplastic cells showed nuclear reactivity. A mosaic pattern of staining with absence of immunoreactivity in a proportion of tumor cells was not interpreted as abnormal (38).

(b) p53 and MDM2: Tumors were considered $\mathrm{p} 53$ positive [p53(P)] when more than $20 \%$ of the tumor cells showed nuclear staining, whereas, carcinomas were considered MDM2 positive $[\mathrm{MDM} 2(\mathrm{P})]$ when the percentage of stained cancerous cells was significantly higher than that of the adjacent normal tissue (24). The latter criterion 
Table 1. Summary of pRb, p53, MDM2 status, kinetic parameters, ploidy status and patients' clinicopathological features

\begin{tabular}{|c|c|c|c|c|c|c|c|c|c|}
\hline \multirow[t]{2}{*}{ Sample } & \multirow[t]{2}{*}{ Sex } & \multirow[t]{2}{*}{ Age } & \multirow[t]{2}{*}{ Smoking } & \multicolumn{3}{|c|}{ pRb Status } & \multicolumn{3}{|c|}{ p53 Status } \\
\hline & & & & IHC & $\underset{\text { D13S153 }}{\text { AIm }}$ & IHC & $\begin{array}{c}\text { SSCP } \\
\text { Analysis }\end{array}$ & $\begin{array}{l}\text { Defective } \\
\text { Exon }\end{array}$ & $\begin{array}{c}\text { Gene } \\
\text { Mutation }\end{array}$ \\
\hline 19 & M & 70 & YES & No & $\mathrm{LOH}$ & $\mathbf{N}$ & - & & \\
\hline 20 & M & 66 & YES & No & $\mathrm{LOH}$ & $\mathrm{N}$ & + & 9 & not examined \\
\hline 22 & M & 70 & YES & No & & $\mathrm{N}$ & - & & \\
\hline 31 & $M$ & 64 & YES & No & $\mathrm{LOH}$ & $\mathbf{N}$ & - & & \\
\hline 36 & $M$ & 57 & NO & No & & $\mathbf{N}$ & - & & \\
\hline 45 & $M$ & 57 & YES & No & ho & $\mathrm{N}$ & - & & \\
\hline 46 & $M$ & 68 & NO & No & $\mathrm{H}$ & $\mathrm{N}$ & - & & \\
\hline 51 & M & 48 & YES & No & $\mathrm{H}$ & $\mathrm{N}$ & - & & \\
\hline 54 & $M$ & 65 & YES & No & $\mathrm{LOH}$ & $\mathrm{N}$ & - & & \\
\hline 62 & $M$ & 57 & YES & No & ho & $\mathrm{N}$ & + & 8 & codon 270, TTT $->$ ATT \\
\hline 66 & $M$ & 58 & YES & No & $\mathrm{LOH}$ & $\mathbf{N}$ & - & & \\
\hline 80 & $M$ & 75 & YES & No & & $\mathbf{N}$ & & & \\
\hline 81 & M & 68 & YES & No & & $\mathrm{N}$ & & & \\
\hline 3 & $M$ & 61 & YES & No & & $\mathbf{N}$ & - & & \\
\hline 21 & $M$ & 70 & YES & No & $\mathrm{H}$ & $\mathbf{N}$ & - & & \\
\hline 30 & $M$ & 75 & YES & No & & $\mathbf{N}$ & - & & \\
\hline 32 & $M$ & 42 & YES & No & & $\mathbf{N}$ & + & 5 & codon 163 , TAC $->$ TGC \\
\hline 37 & $M$ & 71 & NO & No & $\mathrm{LOH}$ & $\mathbf{N}$ & - & & \\
\hline 39 & M & 56 & YES & No & $\mathrm{H}$ & $\mathbf{N}$ & - & & \\
\hline 40 & $M$ & 54 & YES & No & & $\mathbf{N}$ & - & & \\
\hline 41 & $M$ & 67 & YES & No & & $\mathbf{N}$ & + & 4 & codon $110, \mathrm{CGT}->\mathrm{CT}$ \\
\hline 43 & $M$ & 60 & NO & No & & $\mathbf{N}$ & + & 4 & codon $60, \mathrm{CCA}->\mathrm{CCT}$ \\
\hline 44 & $M$ & 72 & NO & No & $\mathrm{H}$ & $\mathbf{N}$ & + & 6 & codon 213, CGA $->$ GA \\
\hline 50 & $M$ & 62 & NO & No & ho & $\mathbf{N}$ & - & & \\
\hline 79 & $M$ & 72 & YES & No & & $\mathbf{N}$ & & & \\
\hline 82 & $M$ & 74 & YES & No & & $\mathbf{N}$ & & & \\
\hline 83 & M & 59 & YES & No & & $\mathbf{N}$ & & & \\
\hline 84 & M & 47 & YES & No & & $\mathbf{N}$ & & & \\
\hline 8 & $\mathrm{~F}$ & 69 & NO & No & & $\mathrm{P}$ & + & 7 & codon 248, CGG $->$ TGG \\
\hline 13 & $M$ & 64 & YES & No & $\mathrm{H}$ & $\mathrm{P}$ & + & 7 & codon $248 \mathrm{CGG}->\mathrm{CTG}$ \\
\hline 24 & $M$ & 62 & YES & No & ho & $\mathbf{P}$ & + & 4 & codon 74, GCC $->$ ACC \\
\hline 38 & $M$ & 53 & YES & No & & $\mathbf{P}$ & - & & \\
\hline 52 & $M$ & 72 & YES & No & $\mathrm{LOH}$ & $\mathrm{P}$ & + & 8 & codon 273, CGT $->$ CAT \\
\hline 67 & M & 71 & NO & No & $\mathrm{H}$ & $\mathrm{P}$ & - & & \\
\hline 71 & M & 67 & YES & No & & $\mathrm{P}$ & & & \\
\hline 72 & M & 73 & YES & No & & $\mathrm{P}$ & & & \\
\hline 73 & $M$ & 67 & YES & No & & $\mathrm{P}$ & & & \\
\hline 74 & M & 74 & YES & No & & $\mathrm{P}$ & & & \\
\hline 5 & M & 61 & YES & No & & $\mathrm{P}$ & + & 7 & codon 244, GGC $->$ TGC \\
\hline 7 & $M$ & 64 & YES & No & $\mathrm{LOH}$ & $\mathrm{P}$ & + & 8 & codon 273, CGT $->$ CTT \\
\hline 10 & $\mathrm{~F}$ & 68 & YES & No & $\mathrm{LOH}$ & $\mathrm{P}$ & + & 4 & codon. 93, CTG $->$ ATG \\
\hline 11 & M & 70 & YES & No & $\mathrm{LOH}$ & $\mathbf{P}$ & + & 8 & codon 280, AGA $->$ ATA \\
\hline 16 & M & 63 & YES & No & $\mathrm{H}$ & $\mathbf{P}$ & - & & \\
\hline 17 & M & 64 & YES & No & $\mathrm{H}$ & $\mathbf{P}$ & - & & \\
\hline 18 & M & 73 & YES & No & $\mathrm{H}$ & $\mathbf{P}$ & + & 7 & codon 230, ACC $->$ AAC \\
\hline 26 & $M$ & 63 & YES & No & & $\mathbf{P}$ & + & 6 & codon $196, \mathrm{CGA}->\mathrm{CCA}$ \\
\hline 42 & $M$ & 76 & YES & No & $\mathrm{LOH}$ & $\mathbf{P}$ & + & 5 & codon 157, GTC $->$ TTC \\
\hline 59 & $M$ & 65 & YES & No & $\mathrm{LOH}$ & $\mathbf{P}$ & + & 5 & codon 143, GTG $->$ GCC \\
\hline 61 & $M$ & 59 & YES & No & $\mathrm{LOH}$ & $\mathbf{P}$ & - & & \\
\hline 68 & $M$ & 61 & YES & No & & $\mathbf{P}$ & - & & \\
\hline 69 & $\mathrm{~F}$ & 50 & YES & No & & $\mathbf{P}$ & & & \\
\hline 70 & M & 66 & YES & No & & $\mathrm{P}$ & + & 7 & codon 233, CAC $->$ TAC \\
\hline 23 & $M$ & 79 & YES & $\mathrm{Ab}$ & $\mathrm{LOH}$ & $\mathbf{N}$ & - & & \\
\hline 25 & M & 63 & NO & $\mathrm{Ab}$ & $\mathrm{H}$ & $\mathbf{N}$ & - & & \\
\hline
\end{tabular}




\begin{tabular}{|c|c|c|c|c|c|c|c|c|c|c|}
\hline \multirow{2}{*}{$\begin{array}{l}\text { p53 Status } \\
\text { Amino } \\
\text { Acid } \\
\text { Substitution }\end{array}$} & \multicolumn{3}{|c|}{ MDM2 Status } & \multirow{2}{*}{$\begin{array}{l}\text { PI } \\
\%\end{array}$} & \multirow{2}{*}{$\begin{array}{l}\text { AI } \\
\\
\%\end{array}$} & \multirow[t]{2}{*}{ Ploidy } & \multicolumn{4}{|c|}{ Clinicopathological Features } \\
\hline & $\begin{array}{c}\text { AIm } \\
\text { D17S179E }\end{array}$ & IHC & $\begin{array}{c}\text { mRNA } \\
\text { Level }\end{array}$ & & & & Histology & $\mathbf{L N}$ & Stage & $\begin{array}{c}\text { Patients } \\
\text { "Follow } \\
\text { Up"* }\end{array}$ \\
\hline \multirow{13}{*}{$\mathrm{F}->\mathrm{F}$} & ho & $\mathbf{N}$ & $\mathrm{NE}$ & NI & 10,6 & $\mathrm{D}$ & $\mathrm{AD}$ & NO & I & $34+$ \\
\hline & NI & $\mathbf{N}$ & $\mathrm{NE}$ & 24,6 & 3,5 & $\mathrm{D}$ & SQ & NO & I & $34+$ \\
\hline & & $\mathbf{N}$ & $\mathrm{NE}$ & 46,6 & 1,5 & D & $\mathrm{AD}$ & NO & I & $34+$ \\
\hline & ho & $\mathbf{N}$ & $\mathrm{OE}$ & 21,2 & 3 & D & $\mathrm{AD}$ & NO & I & 10 \\
\hline & & $\mathbf{N}$ & NE & 28,8 & & A & $\mathrm{AD}$ & YES & III & 10 \\
\hline & ho & $\mathbf{N}$ & NE & 32,9 & 8,9 & $\mathrm{D}$ & $\mathrm{AD}$ & YES & II & 27 \\
\hline & ho & $\mathbf{N}$ & $\mathrm{NE}$ & NI & & $\mathrm{D}$ & $\mathrm{AD}$ & NO & I & $29+$ \\
\hline & $\mathrm{H}$ & $\mathbf{N}$ & $\mathrm{NE}$ & 20,0 & 2,9 & $\mathrm{D}$ & $\mathrm{AD}$ & YES & II & 15 \\
\hline & $\mathrm{LOH}$ & $\mathbf{N}$ & $\mathrm{NE}$ & 32,2 & 3,1 & NI & SQ & NO & I & $28+$ \\
\hline & $\mathrm{LOH}$ & $\mathbf{N}$ & $\mathrm{NE}$ & 41,4 & 1,4 & A & SQ & NO & I & 13 \\
\hline & $\mathrm{LOH}$ & $\mathbf{N}$ & $\mathrm{NE}$ & 33,3 & 2,3 & A & SQ & YES & II & 3 \\
\hline & & $\mathbf{N}$ & $\mathrm{NE}$ & 29,2 & 1,2 & D & SQ & NO & I & $64+$ \\
\hline & & $\mathbf{N}$ & $\mathrm{NE}$ & 19,0 & 1,1 & $\mathrm{D}$ & $\mathrm{AD}$ & NO & I & $48+$ \\
\hline \multirow{7}{*}{$\mathrm{Y}->\mathrm{C}$} & & $P$ & $\mathrm{OE}$ & 28,3 & 1,6 & $\mathrm{~A}$ & SQ & $\mathrm{NO}$ & I & $37+$ \\
\hline & $\mathrm{LOH}$ & $\mathrm{P}$ & $\mathrm{OE}$ & 34,5 & NI & D & SQ & YES & III & 1 \\
\hline & & $P$ & $\mathrm{OE}$ & 28,8 & 5,2 & D & UL & NO & I & $32+$ \\
\hline & & $\mathbf{P}$ & $\mathrm{OE}$ & 26,4 & 0,7 & A & $\mathrm{AD}$ & YES & III & $30+$ \\
\hline & NI & $\mathrm{P}$ & $\mathrm{OE}$ & 28,9 & 3,2 & A & $\mathrm{AD}$ & YES & II & 12 \\
\hline & ho & $P$ & $\mathrm{OE}$ & 54,0 & 0,9 & D & SQ & YES & III & 9 \\
\hline & & $\mathrm{P}$ & $\mathrm{NE}$ & 31,0 & & A & UL & NO & I & 18 \\
\hline FS & & $\mathbf{P}$ & $\mathrm{OE}$ & 38,0 & 0,5 & A & SQ & NO & I & $30+$ \\
\hline $\mathrm{P}->\mathrm{P}$ & & $\mathrm{P}$ & $\mathrm{OE}$ & 21,4 & 3,5 & A & $\mathrm{AD}$ & YES & II & $30+$ \\
\hline \multirow[t]{6}{*}{ FS } & ho & $\mathrm{P}$ & $\mathrm{OE}$ & 22,3 & 0,7 & A & $\mathrm{AD}$ & YES & III & 14 \\
\hline & $\mathrm{H}$ & $P$ & $\mathrm{NE}$ & 18,1 & 1,4 & D & $\mathrm{AD}$ & YES & II & 27 \\
\hline & & $\mathrm{P}$ & & 33,7 & & A & SQ & YES & II & 14 \\
\hline & & $\mathrm{P}$ & & 28,7 & & A & SQ & YES & II & $40+$ \\
\hline & & $P$ & & 13,7 & 2,6 & D & $\mathrm{AD}$ & YES & III & $69+$ \\
\hline & & $\mathrm{P}$ & & 40,9 & 0,6 & $\mathrm{D}$ & SQ & NO & $\mathrm{I}$ & $67+$ \\
\hline $\mathrm{R}->\mathrm{W}$ & & $\mathbf{N}$ & $\mathrm{NE}$ & 31,0 & 1,4 & $\mathrm{D}$ & $\mathrm{AD}$ & $\mathrm{NO}$ & I & $34+$ \\
\hline $\mathbf{R}->\mathbf{L}$ & ho & $\mathbf{N}$ & $\mathrm{NE}$ & 32,8 & & D & SQ & YES & III & 8 \\
\hline \multirow[t]{2}{*}{$\mathrm{A}->\mathrm{T}$} & $\mathrm{LOH}$ & $\mathbf{N}$ & $\mathrm{NE}$ & 26,7 & 0,8 & NI & SQ & NO & I & N/A \\
\hline & & $\mathbf{N}$ & $\mathrm{NE}$ & 39,3 & 3 & A & SQ & YES & III & $30+$ \\
\hline \multirow[t]{6}{*}{$\mathrm{R}->\mathrm{H}$} & $\mathrm{LOH}$ & $\mathbf{N}$ & $\mathrm{NE}$ & 39,0 & 0,6 & A & SQ & NO & III & $29+$ \\
\hline & ho & $\mathbf{N}$ & $\mathrm{NE}$ & 20,2 & 0,6 & D & $\mathrm{AD}$ & NO & I & $24+$ \\
\hline & & $\mathbf{N}$ & & 22,1 & 1,5 & NI & SQ & YES & II & 40 \\
\hline & & $\mathbf{N}$ & & NI & & D & $\mathrm{AD}$ & YES & II & 17 \\
\hline & & $\mathbf{N}$ & & 26,2 & & D & SQ & - & - & - \\
\hline & & $\mathbf{N}$ & & 20,5 & 1,5 & $\mathrm{D}$ & $\mathrm{AD}$ & NO & I & $69+$ \\
\hline $\mathrm{G}->\mathrm{C}$ & & $\mathrm{P}$ & $\mathrm{OE}$ & 32,8 & 6,3 & $\mathrm{~A}$ & $\mathrm{AD}$ & YES & III & 12 \\
\hline $\mathrm{R}->\mathrm{L}$ & ho & $\mathrm{P}$ & OE & 27,2 & 1,2 & A & SQ & YES & II & $35+$ \\
\hline $\mathrm{L}->\mathrm{M}$ & ho & $P$ & $\mathrm{OE}$ & 40,6 & 1,8 & A & UL & YES & II & 9 \\
\hline \multirow{3}{*}{$\mathrm{R}->\mathrm{I}$} & $\mathrm{H}$ & $P$ & $\mathrm{OE}$ & 36,0 & 0,7 & A & SQ & NO & I & $34+$ \\
\hline & NI & $\mathrm{P}$ & $\mathrm{OE}$ & 4,6 & 0,8 & D & $\mathrm{AD}$ & NO & I & 7 \\
\hline & $\mathrm{H}$ & $\mathbf{P}$ & $\mathrm{NE}$ & 27,3 & 1,2 & NI & SQ & NO & II & $34+$ \\
\hline $\mathrm{T}->\mathrm{N}$ & $\mathrm{LOH}$ & $\mathrm{P}$ & $\mathrm{OE}$ & 43,6 & 4,8 & D & SQ & YES & II & 11 \\
\hline $\mathrm{R}->\mathrm{P}$ & & $\mathrm{P}$ & $\mathrm{OE}$ & 29,2 & 0,1 & A & $\mathrm{AD}$ & YES & II & 17 \\
\hline $\mathrm{V}->\mathrm{F}$ & NI & $\mathrm{P}$ & $\mathrm{OE}$ & 43,8 & 0,6 & A & SQ & YES & III & $30+$ \\
\hline \multirow[t]{4}{*}{$\mathrm{V}->\mathrm{A}$} & $\mathrm{LOH}$ & $\mathrm{P}$ & $\mathrm{OE}$ & 30,4 & & A & $\mathrm{AD}$ & NO & I & 25 \\
\hline & $\mathrm{LOH}$ & $\mathrm{P}$ & $\mathrm{OE}$ & 24,5 & 1,1 & D & $\mathrm{AD}$ & YES & III & $26+$ \\
\hline & & $\mathrm{P}$ & $\mathrm{OE}$ & 59,1 & 2,1 & A & SQ & YES & II & 21 \\
\hline & & $\mathrm{P}$ & $\mathrm{NE}$ & NI & 0,9 & A & $\mathrm{AD}$ & YES & II & 23 \\
\hline \multirow[t]{3}{*}{$\mathrm{H}->\mathrm{Y}$} & & $\mathrm{P}$ & $\mathrm{NE}$ & 36,3 & & $\mathrm{D}$ & SQ & NO & I & 63 \\
\hline & $\mathrm{H}$ & $\mathbf{N}$ & $\overline{\mathrm{OE}}$ & 26,7 & 2,6 & $\mathrm{D}$ & $\mathrm{AD}$ & YES & II & 18 \\
\hline & ho & $\mathbf{N}$ & $\mathrm{NE}$ & 21,3 & 1,4 & $\mathrm{D}$ & $\mathrm{AD}$ & NO & I & $\begin{array}{c}33+ \\
\text { Continued) }\end{array}$ \\
\hline
\end{tabular}


Table 1. (Continued)

\begin{tabular}{|c|c|c|c|c|c|c|c|c|c|}
\hline \multirow[t]{2}{*}{ Sample } & \multirow[t]{2}{*}{ Sex } & \multirow[t]{2}{*}{ Age } & \multirow[t]{2}{*}{ Smoking } & \multicolumn{3}{|c|}{ pRb Status } & \multicolumn{3}{|c|}{ p53 Status } \\
\hline & & & & IHC & $\underset{\text { D13S153 }}{\text { AIm }}$ & IHC & $\begin{array}{c}\text { SSCP } \\
\text { Analysis }\end{array}$ & $\begin{array}{l}\text { Defective } \\
\text { Exon }\end{array}$ & $\begin{array}{c}\text { Gene } \\
\text { Mutation }\end{array}$ \\
\hline 85 & $\mathbf{M}$ & 66 & YES & $\mathrm{Ab}$ & & $\mathbf{N}$ & & & \\
\hline 86 & $\mathrm{~F}$ & 68 & YES & $\mathrm{Ab}$ & & $\mathbf{N}$ & & & \\
\hline 27 & M & 70 & NO & $\mathrm{Ab}$ & $\mathrm{LOH}$ & $\mathbf{N}$ & + & 8 & codon 282, CGG -> _GG \\
\hline 33 & $M$ & 59 & YES & $\mathrm{Ab}$ & & $\mathbf{N}$ & - & & \\
\hline 34 & $M$ & 63 & YES & $\mathrm{Ab}$ & & $\mathbf{N}$ & - & & \\
\hline 49 & $M$ & 53 & NO & $\mathrm{Ab}$ & & $\mathbf{N}$ & - & & \\
\hline 87 & M & 64 & YES & $\mathrm{Ab}$ & & $\mathbf{N}$ & & & \\
\hline 53 & $\mathbf{M}$ & 60 & YES & $\mathrm{Ab}$ & $\mathrm{LOH}$ & $\mathrm{P}$ & + & 9 & codon 319, AAG $->$ AAT \\
\hline 78 & M & 69 & YES & $\mathrm{Ab}$ & & $\mathrm{P}$ & & & \\
\hline 1 & $\bar{M}$ & 57 & YES & $\mathrm{Ab}$ & $\mathrm{H}$ & $\mathrm{P}$ & - & & \\
\hline 4 & $M$ & 60 & YES & $\mathrm{Ab}$ & $\mathrm{H}$ & $\mathrm{P}$ & + & 7 & codon 249, AGG $->$ AGT \\
\hline 6 & $M$ & 75 & YES & $\mathrm{Ab}$ & & $\mathrm{P}$ & + & 5 & codon $151, \mathrm{CCC}->\mathrm{CAC}$ \\
\hline 9 & $M$ & 53 & YES & $\mathrm{Ab}$ & $\mathrm{LOH}$ & $\mathrm{P}$ & + & 7 & codon 238, TGT $->$ TTT \\
\hline 12 & $M$ & 70 & YES & $\mathrm{Ab}$ & & $\mathrm{P}$ & + & 7 & codon 234 , TAC $->$ TGC \\
\hline 14 & $M$ & 74 & YES & $\mathrm{Ab}$ & $\mathrm{LOH}$ & $\mathrm{P}$ & + & 7 & codon 239, AAC $->$ ACC \\
\hline 15 & M & 69 & YES & $\mathrm{Ab}$ & $\mathrm{LOH}$ & $\mathrm{P}$ & + & 5 & codon 163 , TAC $->$ TGC \\
\hline 28 & $M$ & 60 & YES & $\mathrm{Ab}$ & $\mathrm{LOH}$ & $\mathrm{P}$ & + & 5 & codon 157, GTC $->$ TTC \\
\hline 29 & $M$ & 61 & YES & $\mathrm{Ab}$ & ho & $\mathrm{P}$ & + & 4 & codon 69, GCT $->$ GGT \\
\hline 35 & $M$ & 67 & YES & $\mathrm{Ab}$ & & $\mathrm{P}$ & - & & \\
\hline 47 & $M$ & 71 & YES & $\mathrm{Ab}$ & $\mathrm{LOH}$ & $\mathrm{P}$ & - & & \\
\hline 48 & M & 73 & YES & $\mathrm{Ab}$ & & $\mathrm{P}$ & + & 7 & codon 237, ATG -> ATA \\
\hline 55 & $M$ & 52 & NO & $\mathrm{Ab}$ & ho & $\mathrm{P}$ & + & 8 & codon 275, TGT $->$ TTT \\
\hline 56 & M & 58 & YES & $\mathrm{Ab}$ & $\mathrm{LOH}$ & $\mathbf{P}$ & - & & \\
\hline 57 & M & 58 & YES & $\mathrm{Ab}$ & $\mathrm{H}$ & $\mathbf{P}$ & + & 5 & codon $153, \mathrm{CCC}->\mathrm{CAC}$ \\
\hline 58 & M & 52 & NO & $\mathrm{Ab}$ & $\mathrm{LOH}$ & $\mathbf{P}$ & - & & \\
\hline 60 & M & 64 & YES & $\mathrm{Ab}$ & $\mathrm{LOH}$ & $\mathrm{P}$ & - & & \\
\hline 63 & $\mathrm{~F}$ & 60 & YES & $\mathrm{Ab}$ & & $\mathrm{P}$ & - & & \\
\hline 64 & $M$ & 62 & YES & $\mathrm{Ab}$ & $\mathrm{LOH}$ & $P$ & - & & \\
\hline 65 & M & 56 & YES & $\mathrm{Ab}$ & ho & $\mathrm{P}$ & - & & \\
\hline 75 & $\mathrm{~F}$ & 33 & YES & $\mathrm{Ab}$ & & $\mathrm{P}$ & & & \\
\hline 76 & M & 51 & YES & $\mathrm{Ab}$ & & $\mathrm{P}$ & & & \\
\hline 77 & $M$ & 69 & YES & $\mathrm{Ab}$ & & $\mathrm{P}$ & & & \\
\hline 2 & $M$ & 60 & YES & NI & $\mathrm{LOH}$ & NI & - & & \\
\hline
\end{tabular}

M: Male, F: female; IHC: Immunohistochemistry, No: Normal expression, Ab: Aberrant expression, P: Positive, N: Negative, NI: Non Informative; AIm: Allelic Imbalance analysis, LOH: Loss of Heterozygosity, H: Heterozygous, ho: homozygous; SSCP: Single Strand Conformation Polymorphism analysis, $+(-)$ : indicates possible mutation (no mutation), FS: frameshift; NE: Normal Expression, OE: OverExpression; PI: Proliferation Index, AI: Apoptotic Index, D: Diploid, A: Aneuploid; SQ: Squamous cell carcinoma, AD: Adenocarcinoma, UL: Undifferentiated Large cell carcinoma, LN: Lymph Node metastasis.

*in months after surgery, $(+)$ indicates that the patient is alive

was set because we previously demonstrated that normal elements of the respiratory tract react with MDM2 antibodies (22). The remaining tumors were scored as negative (N).

(c) Ki-67: Tumor cells were evaluated as positive when nuclear staining without cytoplasmic background was observed. Proliferation index (PI) was estimated as the percentage of $\mathrm{Ki}-67$ positive cells in 5 to 7 High Power
Fields (HPF) (counted cells more than 1000). Slide examination was performed by three independent observers (GR, VG, PF). Intraobserver variability was minimal $(p<0.001)$.

\section{Microdissection and Nucleic Acids Extraction}

Microdissection. For DNA extraction, contiguous $5 \mu \mathrm{m}$ sections were microdissected as previously described (24). 


\begin{tabular}{|c|c|c|c|c|c|c|c|c|c|c|}
\hline \multirow{2}{*}{$\begin{array}{l}\text { p53 Status } \\
\text { Amino } \\
\text { Acid } \\
\text { Substitution }\end{array}$} & \multicolumn{3}{|c|}{ MDM2 Status } & \multirow{2}{*}{$\begin{array}{l}\text { PI } \\
\text { \% }\end{array}$} & \multirow{2}{*}{$\begin{array}{l}\text { AI } \\
\\
\%\end{array}$} & \multirow[t]{2}{*}{ Ploidy } & \multicolumn{4}{|c|}{ Clinicopathological Feature } \\
\hline & $\underset{\text { D17S179E }}{\text { AIm }}$ & IHC & $\begin{array}{c}\text { mRNA } \\
\text { Level }\end{array}$ & & & & Histology & $\mathbf{L N}$ & Stage & $\begin{array}{c}\text { Patients } \\
\text { "Follow } \\
\text { Up"* }\end{array}$ \\
\hline & & $\begin{array}{l}\mathbf{N} \\
\mathbf{N}\end{array}$ & & $\begin{array}{l}\text { NI } \\
19,7\end{array}$ & 0,8 & $\begin{array}{l}\text { NI } \\
\text { A }\end{array}$ & $\begin{array}{l}\text { SQ } \\
\text { AD }\end{array}$ & $\begin{array}{l}\text { YES } \\
\text { YES }\end{array}$ & $\begin{array}{l}\text { II } \\
\text { II }\end{array}$ & $\begin{array}{c}109+ \\
22\end{array}$ \\
\hline \multirow[t]{5}{*}{ FS } & $\mathrm{LOH}$ & $\mathbf{P}$ & $\mathrm{OE}$ & 13,3 & 3,5 & NI & $\mathrm{AD}$ & YES & I & 14 \\
\hline & & $\mathbf{P}$ & $\mathrm{OE}$ & 40,7 & 0,8 & A & SQ & NO & I & 14 \\
\hline & & $\mathrm{P}$ & $\mathrm{OE}$ & 34,7 & 0,5 & D & $\mathrm{AD}$ & NO & I & $32+$ \\
\hline & & $\mathbf{P}$ & $\mathrm{OE}$ & 36,9 & & $\mathrm{D}$ & $\mathrm{AD}$ & NO & I & $29+$ \\
\hline & & $\mathbf{P}$ & & 23,6 & 0,5 & A & $\mathrm{AD}$ & YES & II & 10 \\
\hline \multirow[t]{3}{*}{$\mathrm{K}->\mathrm{N}$} & ho & $\mathbf{N}$ & $\mathrm{NE}$ & 51,2 & 2,6 & A & SQ & YES & III & 15 \\
\hline & & $\mathbf{N}$ & & 26,0 & 0,7 & $\mathrm{D}$ & $\mathrm{AD}$ & NO & III & $72+$ \\
\hline & $\mathrm{H}$ & $\mathbf{P}$ & $\mathrm{NE}$ & 31,1 & 4,8 & A & $\mathrm{AD}$ & YES & III & 3 \\
\hline $\mathrm{R}->\mathrm{S}$ & ho & $\mathrm{P}$ & OE & & NI & A & UL & NO & I & 0 \\
\hline $\mathrm{P}->\mathrm{H}$ & & $\mathbf{P}$ & & 45,6 & 0,6 & A & SQ & YES & II & $35+$ \\
\hline $\mathrm{C}->\mathrm{F}$ & ho & $P$ & $\mathrm{OE}$ & 30,3 & 12 & D & $\mathrm{AD}$ & NO & I & $35+$ \\
\hline $\mathrm{Y}->\mathrm{C}$ & & $P$ & $\mathrm{OE}$ & 29,5 & 0,9 & A & SQ & NO & I & $35+$ \\
\hline $\mathbf{N}->\mathrm{T}$ & ho & $\mathrm{P}$ & $\mathrm{OE}$ & 38,5 & 1,3 & A & SQ & YES & III & 8 \\
\hline $\mathrm{Y}->\mathrm{C}$ & $\mathrm{LOH}$ & $P$ & $\mathrm{OE}$ & 40,6 & 1,1 & A & SQ & NO & I & $34+$ \\
\hline $\mathrm{V}->\mathrm{F}$ & ho & $P$ & $\mathrm{OE}$ & 40,9 & 1,5 & A & SQ & NO & I & $33+$ \\
\hline \multirow[t]{3}{*}{$A->G$} & ho & $\mathrm{P}$ & $\mathrm{OE}$ & 43,4 & 2,7 & A & UL & YES & III & 0 \\
\hline & & $\mathrm{P}$ & $\mathrm{NE}$ & 29,2 & 0,8 & A & $\mathrm{AD}$ & YES & I & 17 \\
\hline & ho & $\mathrm{P}$ & $\mathrm{OE}$ & 54,4 & 0,5 & A & SQ & NO & I & 25 \\
\hline$M->I$ & & $\mathrm{P}$ & & 44,0 & 0,5 & D & SQ & NO & III & 14 \\
\hline \multirow[t]{2}{*}{$\mathrm{C}->\mathrm{F}$} & ho & $\mathrm{P}$ & $\mathrm{OE}$ & 43,3 & 0,8 & $\mathrm{~A}$ & $\mathrm{AD}$ & YES & II & 10 \\
\hline & ho & $\mathrm{P}$ & $\mathrm{NE}$ & 47,3 & 0,4 & A & SQ & YES & II & 11 \\
\hline \multirow[t]{10}{*}{$\mathrm{P}->\mathrm{H}$} & NI & $\mathrm{P}$ & $\mathrm{OE}$ & 40,0 & 1,8 & A & SQ & YES & III & 8 \\
\hline & ho & $\mathrm{P}$ & $\mathrm{OE}$ & 46,0 & 0,6 & A & $\mathrm{AD}$ & YES & II & $26+$ \\
\hline & $\mathrm{H}$ & $\mathrm{P}$ & $\mathrm{OE}$ & 38,6 & 1 & A & $\mathrm{AD}$ & YES & III & 23 \\
\hline & & $\mathrm{P}$ & $\mathrm{OE}$ & 50,6 & 1 & A & $\mathrm{AD}$ & NO & III & $25+$ \\
\hline & $\mathrm{LOH}$ & $\mathrm{P}$ & $\mathrm{OE}$ & 39,3 & 1,6 & D & $\mathrm{AD}$ & NO & I & $25+$ \\
\hline & $\mathrm{LOH}$ & $\mathrm{P}$ & $\mathrm{OE}$ & 70,4 & 0,7 & A & SQ & YES & II & 22 \\
\hline & & $\mathrm{P}$ & & 39,1 & 0,5 & A & $\mathrm{AD}$ & YES & III & 0 \\
\hline & & $\mathrm{P}$ & & 34,0 & 0,4 & A & SQ & YES & II & 1 \\
\hline & & $\mathrm{P}$ & & 42,1 & 0,3 & $\mathrm{D}$ & SQ & NO & II & $73+$ \\
\hline & $\mathrm{LOH}$ & NI & & NI & & NI & SQ & YES & III & 21 \\
\hline
\end{tabular}

DNA extraction. DNA was extracted from $50 \mu \mathrm{g}$ of neoplastic material using the phenol/ chloroform/isoamylalcohol method (39).

RNA EXTRACTION. Cancerous material with more than $\mathbf{9 0 \%}$ tumor cells was used for RNA extraction, because microdissection was not suitable for RNA handling methods. RNA was extracted with Trizol reagent (Life Technologies, AntiSel, Greece) according to the manufacturer's instructions. The quality and quantity of RNA was assessed by formaldehyde denaturing agarose gel electrophoresis and spectrophotometry at 260 and $280 \mathrm{~nm}$.

\section{p53 Gene Analysis}

In this study, additional mutation analysis by single strand conformation polymorphism (SSCP) and automated sequencing (24) was performed in samples 62, 32, 44, 24, 70, 27 and 28 , which were not examined in our previous study (24).

\section{Allelic Imbalance (AIm) Analysis of Microsatellite} Loci D13S153 and D17S179E

To examine allelic alterations of $R B 1$ and $p 53$, we chose two markers: D13S153, which was selected from the Linkage Mapping Set v2.0 (PE- 
Applied Biosystems, Warrington, U.K.) and lies within the RBI gene; and D17S179E, a pentanucleotide marker located within the first intron of $p 53$.

PRIMERS. The DI7S179E amplimers (designed using Oligo-version 4.01, National Biosciences Inc., Plymouth, MA) produce a 161bp fragment and their sequences were:

\section{5'-AGT AAG CGG AGA TAG TGC CA-3' 5'-GCA CTG ACA AAA CAT CCC CT-3'.}

METHOD. The markers were amplified in a panel of duplex reactions. The reaction mixture consisted of: 1xGeneAmp buffer II, $250 \mu \mathrm{M}$ dNTPs, $2 \mathrm{mM} \mathrm{MgCl} 2,0.5 \mu \mathrm{M}$ of each amplimer and $2 \mathrm{u}$ AmpliTaq Gold polymerase. The polymerase chain reaction (PCR) thermal profile was the following: initial denaturation for $2 \mathrm{~min}$ at $95^{\circ} \mathrm{C}, 30$ cycles of $30 \mathrm{sec}$ at $94^{\circ} \mathrm{C}, 30 \mathrm{sec}$ at $55^{\circ} \mathrm{C}$ and $30 \mathrm{sec}$ at $72^{\circ} \mathrm{C}$, followed by a final extension step of $20 \mathrm{~min}$ at $72^{\circ} \mathrm{C}$. PCR products were denatured in loading buffer (size marker ROX-350/dextran blue/formamide: $1 / 1 / 5$ ), at $95^{\circ} \mathrm{C}$ for $5 \mathrm{~min}$ and analyzed on an ABI-PRISM 377 Automatic Sequencer (PE-Applied Biosystems). Results were evaluated using the Genescan and Genotyper software (PE-Applied Biosystems).

EVALUATION. The variability of the reaction and the establishment of the cutoff level for scoring allelic imbalance have been previously described (40). When the allele ratio values were $\leq 0.65$ or $\geq 1.54$, samples were scored as loss of heterozygosity ( $\mathrm{LOH})$; whereas, when their values covered the range 0.77-1.23, they were scored as negative. Samples exhibiting values between $1.23-1.54$ or $0.65-0.77$ were subjected to a second assay and scored as LOH only when a second positive value was obtained.

Table 2. Association among pRb, p53, MDM2, pRb/p53/MDM2 patterns, number of alterations and clinicopathological features, proliferation index, apoptotic rate and ploidy status

\begin{tabular}{|c|c|c|c|c|c|c|c|c|c|c|c|c|c|c|}
\hline \multicolumn{2}{|c|}{ Expression } & \multicolumn{4}{|c|}{ Smoking History } & \multicolumn{2}{|c|}{ Histology } & \multicolumn{4}{|c|}{ Lymph Node Invasion } & \multicolumn{3}{|c|}{ Stage } \\
\hline & & No & Yes & $p$ & SQ & AD & UL & $p$ & - & + & $p$ & I & II & III \\
\hline \multirow[t]{2}{*}{$\mathrm{pRb}$ IHC } & $\mathrm{Ab}$ & 5 & 28 & 1.000 & 14 & 17 & 2 & 0.876 & 15 & 18 & 1.000 & 13 & 10 & 10 \\
\hline & No & 8 & 44 & & 25 & 24 & 3 & & 24 & 27 & 22 & 17 & 12 & \\
\hline \multirow[t]{2}{*}{ p53 IHC } & $\mathbf{P}$ & 4 & 45 & 0.064 & 26 & 20 & 3 & 0.268 & 21 & 27 & 0.660 & 16 & 16 & 16 \\
\hline & $\mathrm{N}$ & 9 & 27 & & 13 & 21 & 2 & & 18 & 18 & & 19 & 11 & 6 \\
\hline \multirow[t]{2}{*}{ MDM2 IHC } & $\mathrm{P}$ & 8 & 49 & 0.751 & 26 & 26 & 5 & 0.259 & 23 & 34 & 0.159 & 21 & 20 & 16 \\
\hline & $\mathbf{N}$ & 5 & 23 & & 13 & 15 & 一 & & 16 & 11 & & 14 & 7 & 6 \\
\hline \multirow[t]{8}{*}{$\begin{array}{c}\mathrm{pRb} / \mathrm{p} 53 / \\
\text { MDM2 }\end{array}$} & No/N/N & 2 & 11 & 0.295 & 6 & 7 & - & 0.759 & 9 & 4 & 0.615 & 9 & 3 & 1 \\
\hline & $\mathrm{Ab} / \mathrm{N} / \mathrm{N}$ & 1 & 2 & & 3 & - & - & & 1 & 2 & & 1 & 2 & - \\
\hline & $\mathrm{No} / \mathrm{P} / \mathrm{N}$ & 2 & 8 & & 4 & 6 & 一 & & 5 & 4 & & 4 & 2 & 3 \\
\hline & $\mathrm{No} / \mathrm{N} / \mathrm{P}$ & 4 & 11 & & 7 & 6 & 2 & & 5 & 10 & & 5 & 5 & 5 \\
\hline & $\mathrm{Ab} / \mathrm{P} / \mathrm{N}$ & - & 2 & & 1 & 1 & 一 & & 1 & 1 & & 一 & 一 & 2 \\
\hline & $\mathrm{Ab} / \mathrm{N} / \mathrm{P}$ & 2 & 3 & & 4 & 1 & - & & 3 & 2 & & 4 & 1 & - \\
\hline & $\mathrm{No} / \mathrm{P} / \mathrm{P}$ & - & 14 & & 6 & 7 & 1 & & 5 & 9 & & 4 & 7 & 3 \\
\hline & $\mathrm{Ab} / \mathrm{P} / \mathrm{P}$ & 2 & 21 & & 9 & 12 & 2 & & 10 & 13 & & 8 & 7 & 8 \\
\hline \multirow[t]{4}{*}{ Alterations } & 0 & & & & & & & & & & & & & \\
\hline & 1 & & & & & & & & & & & & & \\
\hline & 2 & & & & & & & & & & & & & \\
\hline & 3 & & & & & & & & & & & & & \\
\hline
\end{tabular}

A, Aneuploid; Ab, Aberrant; AD, Adenocarcinoma; D, Diploid; N, Negative; No, Normal; P, Positive; SQ, Squamous cell carcinoma; UL, Undifferentiated Large cell carcinoma. 
Multiplex Reverse Transcription (RT)-PCR

To examine the mRNA levels of MDM2 in tumor and adjacent normal tissues, we performed a semi-quantitative multiplex RT-PCR method. A target mRNA fragment was co-amplified with a larger reference mRNA fragment of a ubiquitously expressed molecule (41). The relative ratios of the amplification products in the tumor samples reflected the relative proportion of input mRNAs and were compared with the relative ratios of the corresponding normal tissue (41).

CDNA SYNTHESIS. cDNA from $5 \mu \mathrm{g}$ of total RNA was synthesized using oligo-dT and MMLV reverse transcriptase (Life Technologies) according to manufacturer's instructions.

PRIMERS. The primers used in the reaction were the following:

Target $c D N A$ : The conservative area of the MDM2 gene, where the nuclear localization and the nuclear export signals were located, was amplified (42). The amplimers were:

$\Delta$ 5'-AGG TGG GAG TGA TCA AAA GG-3' (Pos. 701); and

$\Delta$ 5'-CCT GAT CCA ACC AAT CAC CT-3' (Pos. 1026).

- Reference $c D N A$ : A 548 bp $\beta$-actin fragment was used as reference.

METHOD. The PCR reactions were performed in $30 \mu \mathrm{l}$ containing $10 \mu \mathrm{M}$ Tris- $\mathrm{HCl}, \mathrm{pH} 8.8,50 \mu \mathrm{M}$ $\mathrm{KCl}, 1.5 \mathrm{mM} \mathrm{MgCl}, 0.1 \%$ Triton X-100, 200 $\mu \mathrm{M}$ of each dNTP (dATP, dCTP, dGTP and dTTP), $30 \mu \mathrm{M}$ of each $M D M 2$ primer, $20 \mu \mathrm{M}$ of each $\beta$-actin primer, $5 \mu \mathrm{l}$ of the cDNA pool and $1 \mathrm{u}$ of Taq DNA polymerase (Promega, Bioanalytica, Athens, Greece). The thermal cycle profile was denaturation at $95^{\circ} \mathrm{C}$ for 2 min before the addition of Taq polymerase, followed by 25 cycles of $1 \mathrm{~min}$ at $95^{\circ} \mathrm{C}, 1 \mathrm{~min}$ at $60^{\circ} \mathrm{C}$, and $1 \mathrm{~min}$ at $72^{\circ} \mathrm{C}$. PCR products were analyzed in $2 \%$ agarose gels stained with ethidium bromide.

\begin{tabular}{|c|c|c|c|c|c|c|c|c|c|}
\hline \multicolumn{4}{|c|}{ Proliferation Index } & \multicolumn{3}{|c|}{ Apoptotic Index } & \multicolumn{3}{|c|}{ Ploidy Status } \\
\hline$p$ & Mean (n) & StDev & $p$ & Mean (n) & StDev & $p$ & $\mathbf{A}$ & D & $p$ \\
\hline \multirow[t]{2}{*}{0.788} & $37.88(32)$ & 11.34 & 0.002 & $1.174(31)$ & 1.029 & 0.006 & 23 & 9 & 0.034 \\
\hline & $30.65(48)$ & 9.95 & & $2.223(41)$ & 2.21 & & 23 & 25 & \\
\hline \multirow[t]{2}{*}{0.129} & $36.71(46)$ & 11.32 & 0.001 & $1.353(43)$ & 1.28 & 0.011 & 31 & 15 & 0.037 \\
\hline & $29.26(34)$ & 9.2 & & $2.390(29)$ & 2.39 & & 15 & 19 & \\
\hline \multirow[t]{2}{*}{0.426} & $36.02(53)$ & 11.26 & 0.001 & $1.450(48)$ & 1.409 & 0.004 & 38 & 15 & $<0.001$ \\
\hline & $28.68(27)$ & 8.96 & & $2.420(24)$ & 2.45 & & 8 & 19 & \\
\hline \multirow[t]{12}{*}{0.153} & $28.59(13)$ & 9.13 & 0.001 & $3.460(12)$ & 3.063 & 0.022 & 4 & 10 & 0.034 \\
\hline & $22.57(3)$ & 3.67 & & $1350(3)$ & 1.236 & & 1 & 2 & \\
\hline & $28.64(9)$ & 7.36 & & $1.327(7)$ & 0.823 & & 2 & 6 & \\
\hline & $31.25(13)$ & 9.43 & & $1.850(10)$ & 1.584 & & 8 & 5 & \\
\hline & $38.60(2)$ & 17.82 & & $1.633(2)$ & 1.321 & & 1 & 1 & \\
\hline & $29.84(5)$ & 11.22 & & $1.329(4)$ & 1.455 & & 2 & 2 & \\
\hline & $33.49(13)$ & 12.75 & & $1.824(12)$ & 1.865 & & 9 & 4 & \\
\hline & $41.74(22)$ & 9.22 & & $1.080(22)$ & 0.972 & & 18 & 4 & \\
\hline & $28.59(13)$ & 9.13 & $<0.001$ & $3.457(12)$ & 3.063 & 0.001 & 3 & 9 & 0.011 \\
\hline & $29.27(25)$ & 8.46 & & $1.629(20)$ & 1.241 & & 12 & 14 & \\
\hline & $33.11(18)$ & 12.33 & & $1.693(18)$ & 1.665 & & 12 & 7 & \\
\hline & $41.74(22)$ & 9.22 & & $1.080(20)$ & 0.972 & & 19 & 4 & \\
\hline
\end{tabular}




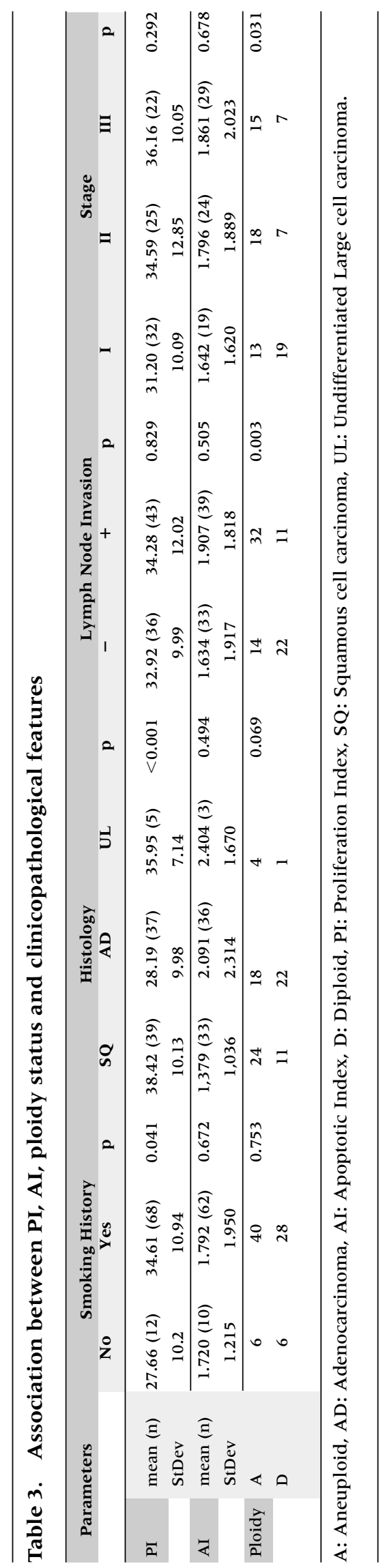


CONTROLs. (a) Contamination of RNA solutions with DNA was assessed by performing PCR reactions directly on RNA. Contaminated RNA solutions were treated with DNAase and/or $4 \mathrm{M} \mathrm{LiCl}_{2}$. (b) To avoid possible RT-PCR intra-assay alterations that could affect the original transcript ratio (target vs. reference), two-fold serial dilutions of RNA solutions were employed in control amplifications. From these reactions, a low number of PCR cycles was established in order to obtain accurate variations of RNA transcript ratios.

EVALUATION. The relative ratio of MDM2/ $\beta$-actin was quantified using an image analysis system (Media Cybernetics, Silver Spring, MD). Because $\beta$-actin amplification was not necessarily similar to that of $M D M 2$, comparison of the relative ratios of MDM2 and $\beta$-actin for each sample, between corresponding tumor and normal specimens, was performed [MDM2/ $\beta$-actin (Tumor): MDM $2 / \beta$-actin (Normal)].

\section{Tdt-mediated dUTP Nick End Labeling Assay (TUNEL)}

METHOD. Double-strand DNA breaks were detected by TUNEL according to the method of Gavrieli et al. (43). Briefly, $5 \mu \mathrm{m}$ paraffin sections were mounted on poly-L-lysine coated slides, dewaxed, rehydrated and incubated for 30 min with $0.3 \%$ hydrogen peroxide to quench the endogenous peroxidase activity. Pretreatment was carried out by incubating the sections with Proteinase K (Sigma, Athens, Greece); $(20 \mu \mathrm{g} / \mathrm{ml})$ for $15 \mathrm{~min}$ at $37^{\circ} \mathrm{C}$. The labeling step was performed with TdT ( $15 \mathrm{u}$ per slide) (New England Biolabs, Bioline, Greece) for $\mathrm{l} \mathrm{hr}$ at $37^{\circ} \mathrm{C}$ in $25 \mathrm{mM}$ Tris- $\mathrm{Cl} \mathrm{pH} 7.2$, $200 \mathrm{mM}$ potassium cacodylate, $0.25 \mathrm{mM} \mathrm{CoCl}{ }_{2}$, $250 \mathrm{mg} / \mathrm{ml}$ bovine serum albumin (BSA), $24 \mu \mathrm{M}$ biotin-dATP (Life Technologies, AntiSel, Greece). The reaction was stopped by rinsing the sections in 20mM EDTA. The next stage comprised a 30 min incubation in StreptAB Complex solution ( $1: 100$ stock biotin solution, 1:100 stock streptavidin-hyperoxidase solution; Dako, Kali-fronas, Greece). For color development, we used 3,3'-diaminobenzidine tetrahydrochloride (DAB) as chromogen and hematoxylin as counterstain.
CONTROLs. For positive controls we used tissue sections incubated with DNAse I prior to treatment with TdT and, for negative ones, we used sections incubated in TdT buffer without the presence of the enzyme.

evaluation. Cells were considered to undergo apoptosis when nuclear staining, without cytoplasmic background, was observed. AI was estimated as the percentage of apoptotic cells in 10 HPFs (counted cells: 9001000). Slide examination was performed by three independent observers (PF, VG, GR). Intraobserver variability was minimal $(p<$ $0.001)$.

\section{Nuclear DNA Ploidy Analysis}

METHOD. The samples were stained according to the Thionin-Feulgen procedure (44). Briefly, $5 \mu \mathrm{m}$ paraffin sections were dewaxed, rehydrated in descending alcoholic solutions and subjected to acidic hydrolysis in $5 \mathrm{~N} \mathrm{HCl}$ at $\mathrm{RT}$ for $1 \mathrm{hr}$. Then the sections were stained with Thionin-Schiff's reagent $(0.5 \%$ thionin, $0.5 \%$ sodium bisulfide, $0.1 \mathrm{~N} \mathrm{HCl}$ ) for $90 \mathrm{~min}$ at RT. Next, specimens were washed three times ( $30 \mathrm{sec}, 5 \mathrm{~min}$ and $10 \mathrm{~min}$ ) in freshly prepared sulfide rinsing solution $(0.5 \%$ sodium bisulfide, $0.05 \mathrm{~N} \mathrm{HCl}$ ) and once under running tap water for $10 \mathrm{~min}$. An additional rinsing step in acidic alcohol $(70 \%$ alcohol, $0.1 \mathrm{~N} \mathrm{HCl})$ was used to increase the staining contrast. Finally, the sections were dehydrated in ascending alcoholic scale and mounted in a xylene-based material.

EVALUATION. The measuring procedure was performed using the Optipath TV-based image analysis system (Meyer Instruments, Houston, TX) equipped with a microscope and a video CCD camera. As internal reference control, lymphocytes or granulocytes were used. In each analysis, approximately 100 control and 350 tumor cells were measured. To distinguish non-diploid cells from diploid, an upper limit of 2.5c was set for diploid values. Because the fraction above $2.5 \mathrm{c}$ might include proliferating diploid cells, we also calculated the fraction of tumor cells with DNA values above the $5 \mathrm{c}$ level, which exceeded those of proliferating diploid cells. Cases with more than $5 \%$ of cells with DNA content above the $5 \mathrm{c}$ limit were considered aneuploid (45). 
Table 4. Association between PI, AI, PI/AI, ploidy and number of alterations

\begin{tabular}{|c|c|c|c|c|c|c|c|}
\hline & & \multicolumn{4}{|c|}{ Analysis of Variance } & \multirow{2}{*}{\multicolumn{2}{|c|}{$\begin{array}{c}\text { Logistic Regression Analysis } \\
\text { Ploidy }\end{array}$}} \\
\hline & & \multicolumn{2}{|l|}{ PI } & \multicolumn{2}{|l|}{$\log A \mathrm{I}$} & & \\
\hline & & Mean Difference( $95 \% \mathrm{CI})$ & $p$ & Mean Difference $(95 \% \mathrm{CI})$ & $p$ & Odds Ratio(95\%CI) & $p$ \\
\hline Intercept & & $28.61(23.17,34.09)$ & $<0.001$ & $0.973(0.501-1.444)$ & $<0.001$ & 一 & 0.121 \\
\hline 3 alterations & & $13.17(6.30,20.04)$ & $<0.001$ & $-1.145(-1.731,-0.558)$ & $<0.001$ & $11.87(2.44,57.85)$ & 0.002 \\
\hline 2 alterations & & $4.50(-2.50,11.49)$ & 0.204 & $-0.836(-1.445,0.227)$ & 0.008 & $4.29(0.97,18.97)$ & 0.055 \\
\hline 1 alteration & & $0.67(-6.40,7.39)$ & 0.842 & $-0.831(-1.423,0.235)$ & 0.007 & $2.11(0.52,8.67)$ & 0.298 \\
\hline \multirow[t]{5}{*}{0 alteration } & & - & & - & & - & \\
\hline & & & & & & & \\
\hline & & \multicolumn{6}{|c|}{ Multiple Comparisons' Analysis } \\
\hline & & \multicolumn{2}{|l|}{ PI } & \multicolumn{2}{|l|}{$\log A I$} & \multicolumn{2}{|l|}{ PI/AI } \\
\hline & & Mean Difference(95\% CI) & $p$ & Mean Difference( $95 \% \mathrm{CI})$ & $p$ & Mean Difference( $95 \% \mathrm{CI})$ & $p$ \\
\hline \multicolumn{8}{|l|}{ Intercept } \\
\hline \multirow[t]{2}{*}{3 alterations } & LSD & $13.17(6.30,20.04)$ & $<0.001$ & $-1.144(-1.731,-0.558)$ & $<0.001$ & $48.05(15.83,80.27)$ & 0.004 \\
\hline & Scheffe & $13.17(3.31,23.03)$ & 0.004 & $-1.144(-1.987,-0.302)$ & 0.003 & $48.05(1.75,94.35)$ & 0.039 \\
\hline \multirow[t]{2}{*}{2 alterations } & LSD & $4.50(-2.50,11.49)$ & 0.204 & $-0.836(-1.445,0.227)$ & 0.008 & $26.80(-6.96,60.56)$ & 0.118 \\
\hline & Scheffe & $4.50(-5.55,14.54)$ & 0.652 & $-0.836(-1.710,0.039)$ & 0.067 & $26.80(-21.71,75.32)$ & 0.147 \\
\hline \multirow[t]{2}{*}{1 alteration } & LSD & $0.67(-6.40,7.39)$ & 0.842 & $-0.831(-1.428,0.235)$ & 0.007 & $24.05(-8.70,56.80)$ & 0.147 \\
\hline & Scheffe & $0.67(-8.97,10.31)$ & 0.998 & $-0.831(-1.689,0.026)$ & 0.061 & $24.05(-23.02,71.11)$ & 0.546 \\
\hline \multirow[t]{3}{*}{0 alteration } & & - & & - & & * & \\
\hline & & \multicolumn{2}{|l|}{ PI } & \multicolumn{2}{|l|}{$\log \mathrm{AI}$} & \multicolumn{2}{|l|}{ PI/AI } \\
\hline & & Mean Difference(95\% CI) & $p$ & Mean Difference $(95 \% \mathrm{CI})$ & $p$ & Mean Difference $(95 \% \mathrm{CI})$ & $p$ \\
\hline \multicolumn{8}{|l|}{ Intercept } \\
\hline \multirow[t]{2}{*}{0 alteration } & LSD & $-13.17(-20.04,-6.30)$ & $<0.001$ & $1.144(0.558,1.731)$ & $<0.001$ & $-48.05(-80.27,-15.83)$ & 0.004 \\
\hline & Scheffe & $-13.17(-23.03,-3.31)$ & 0.004 & $1.144(0.302,1.987)$ & 0.003 & $-48.05(-94.35,-1.75)$ & 0.039 \\
\hline \multirow[t]{2}{*}{1 alterations } & LSD & $-12.49(-18.23,-6.75)$ & $<0.001$ & $0.313(-0.192,0.818)$ & 0.220 & $-24.00(-50.96,2.95)$ & 0.080 \\
\hline & Scheffe & $-12.49(-20.73,-4.25)$ & 0.001 & $0.313(-0.412,1.039)$ & 0.677 & $-24.00(-62.74,14.73)$ & 0.375 \\
\hline \multirow[t]{2}{*}{2 alterations } & LSD & $-8.67(-14.74,-2.61)$ & 0.006 & $0.309(-0.211,0.828)$ & 0.240 & $-21.25(-49.43,6.92)$ & 0.137 \\
\hline & Scheffe & $-8.67(-17.38,0.04)$ & 0.051 & $0.309(-0.438,1.055)$ & 0.705 & $-21.25(-61.74,19.24)$ & 0.523 \\
\hline 3 alterations & & - & & - & & - & \\
\hline
\end{tabular}

PI: Proliferation Index, AI: Apoptotic Index

*Mean Value: 15.18

\section{Statistical Analysis}

The possible associations among pRb, p53 and MDM2 status, independently, among $\mathrm{pRb} / \mathrm{p} 53 / \mathrm{MDM} 2$ patterns and the number of alterations with PI, logAI, ploidy status and clinicopathological parameters, were assessed with the nonparametric Kruskal-Wallis and Pearson's Chi-square tests (Tables 2 and 3). Furthermore, analysis of variance (ANOVA) was used to evaluate more specifically the possible association among the number of alterations, and PI and logAI (Table 4). Logistic regression model formulation was applied for estimating possible associations among the number of alterations and ploidy status (Table 4). For multiple comparisons among alterations of the protein-network and the kinetic parameters of the tumors, the Scheffe and the LSD tests were performed (Table 4); whereas, multinomial logit models were used to examine their possible associations with the various clinicopathological parameters. Finally, the Kaplan-Meyer methodology was employed for assessing the survival curves of the parameters examined in the present study. Differences among survival curves were examined by the log-rank test. All the analysis was performed with the SAS statistical package (SAS Institute Inc., Cary, NC). The statistical difference was considered significant when the $p$-value was $<0.05$. It should be noted that samples 73 and 85 were excluded from the Kaplan-Meyer analysis, since their values were beyond the limits of the survival test. 


\section{Results}

$p R b, p 53$ and MDM2 Analysis

pRb STATUS. Aberrant expression of pRb was observed in 33 of the 85 informative cases $(39 \%)$ (Fig. 2a). Statistical analysis between pRb staining and clinicopathological parameters did not indicate any significant association (Table 2). Normal and tumor genomic material was available from 56 samples for AIm analysis. Twenty-six out of 40 informative cases $(65 \%)$ displayed loss of heterozygosity $(\mathrm{LOH})$ (Fig. 3a). Concordance between pRb protein loss and AIm was noticed in 12 cases $(30 \%$; Table 1). There was no association between LOH and clinicopathological data.

A)

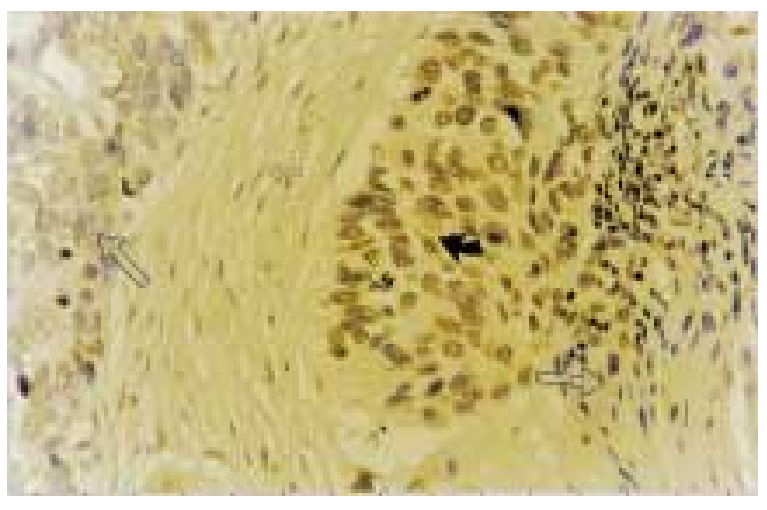

p53 STATUS. Expression of p53 was found in 49 out of 85 informative samples $(57 \%)$. A tendency between p53 immunoreactivity and smoking history was noticed [45/72 (63\%) vs. 27/72 (37\%); $p=0.064$, Table 2]. Additional sequence analysis in our extended database revealed $p 53$ mutations in 31 out of the 70 cases examined with SSCP analysis (46\%; Table 1, Fig. 4). Twenty-six mutations were missense, two were silent (cases 43 and 62) and three were frameshift ones (cases 27, 41 and 44; Table 1, Fig. 5). Another sample (case 20) showed tumor-specific mobility shifts in SSCP analysis, but further sequencing was not performed because material was not available. A highly significant association was observed be-

B)

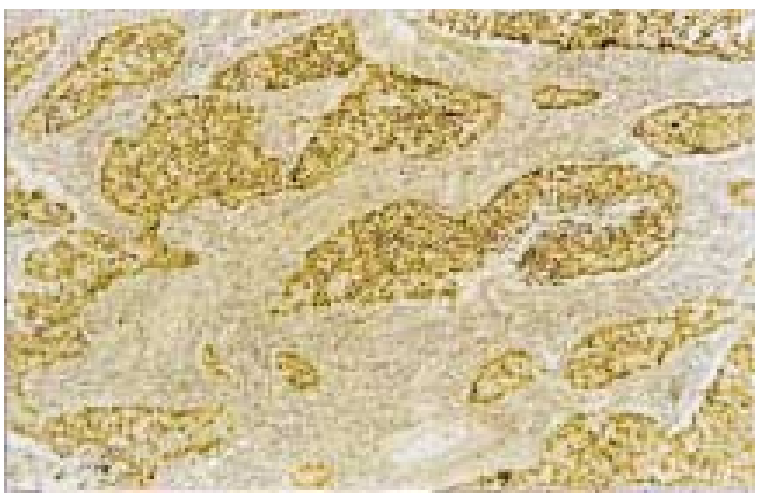

C)

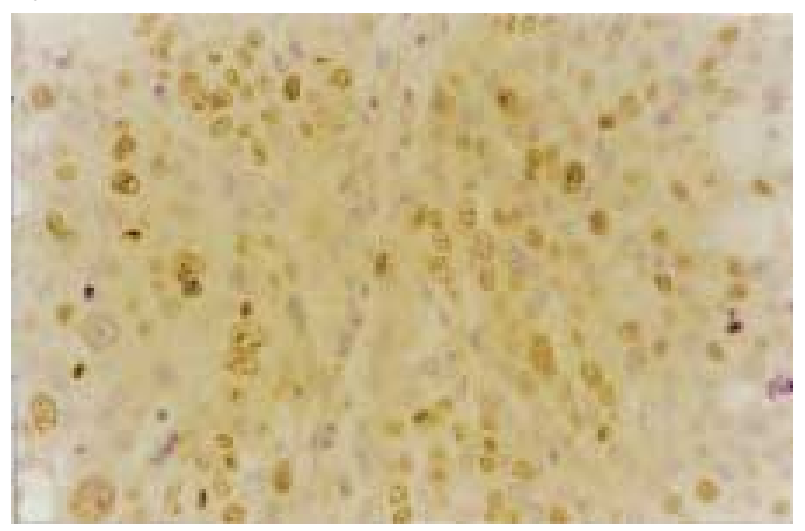

Fig. 2. Representative immunohistochemical results (see Methods). (A) Squamous cell lung carcinoma (case 6) with heterogenous aberrant pRb expression (see Methods). Streptavidin-biotin peroxidase technique with "Rbl" anti-pRb antibody and hematoxylin counterstain $(\times 400)$. [Thick and thin] arrows indicate an "Rbl" positive and negative portion of the tumor area, respectively; whereas, an "Rbl" positive stromal cell is pointed by a small arrow. (B) Squamous cell lung carci- noma (case 3) with MDM2 protein overexpression. Streptavidin-biotin peroxidase technique with "SMP14" anti-MDM2 antibody (DAB as chromogen) and hematoxylin counterstain $(\times 200)$. (C) Squamous cell lung carcinoma (case 62) with high proliferative activity (proliferation index, $\mathrm{PI}=41 \%)$. Streptavidin-biotin peroxidase technique (DAB as chromogen) with "MIB-1" antiKi67 antibody and hematoxylin counterstain $(\times 400)$. 


\section{A) D13S153}

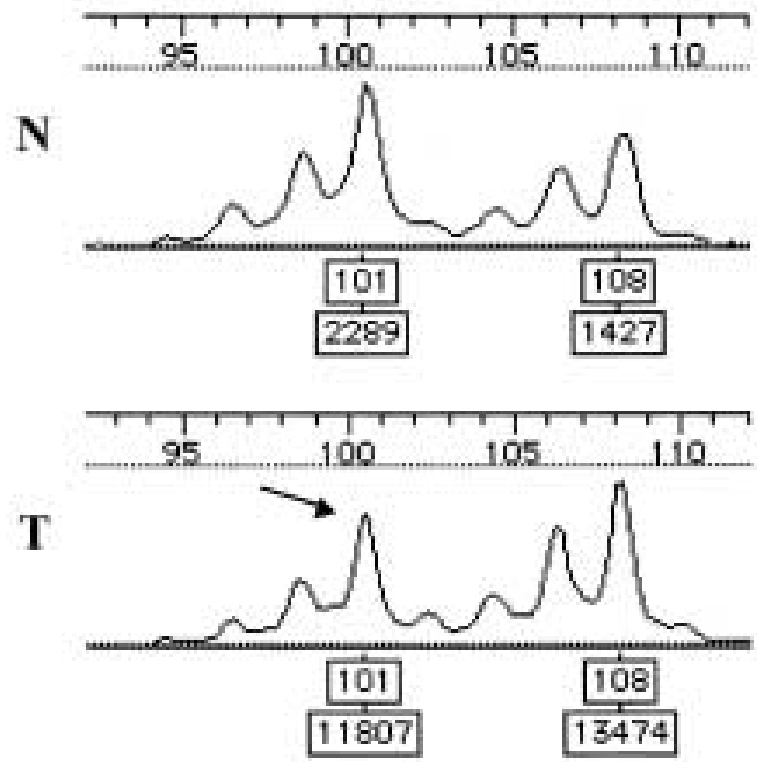

B) $D 17 S 179 E$

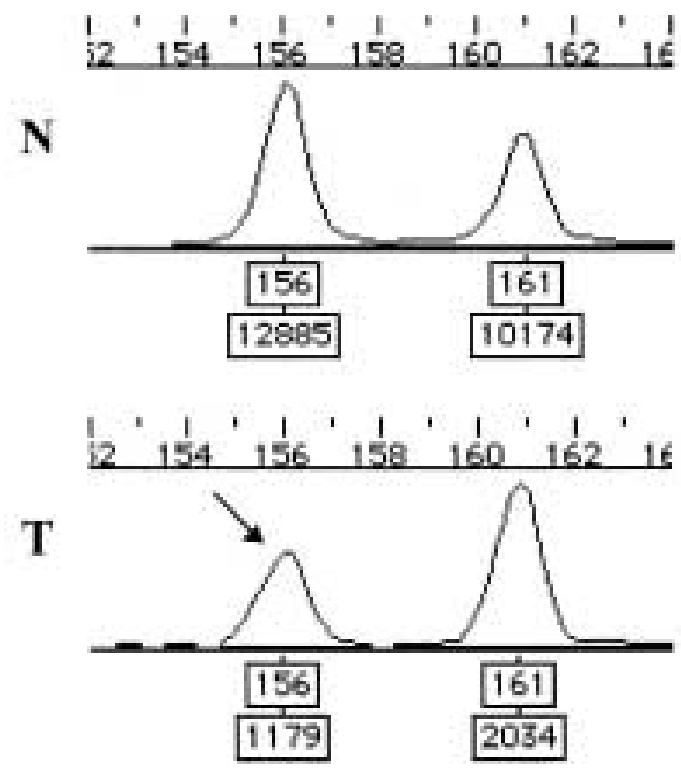

Fig. 3. Representative results of allelic imbalance analysis (see Methods). (A) With chromosome marker D13S153 (case 2). (B) With chromosome marker D17S179E (case 21). N: Normal sample, T: Tumor sample. Loss of heterozygosity $(\mathrm{LOH})$ is indicated by an arrow.

tween $p 53$ gene mutations and p53 immunopositivity (positive vs. negative) [25/40 (63\%) vs $7 / 29(24 \%), p=0.004$ by Pearson's Chi-square test]. DNA from 56 samples was suitable for AIm analysis at the D17S179E locus. LOH was

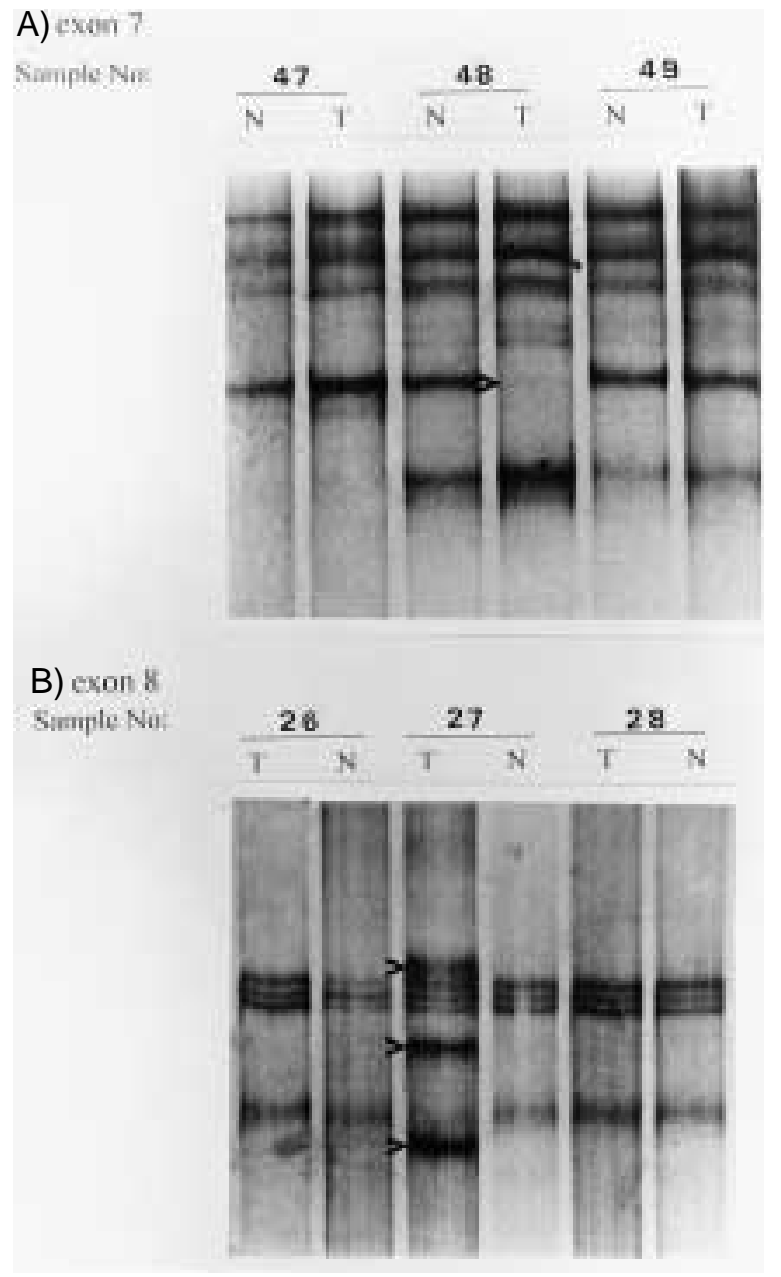

Fig. 4. Representative results of the single strand conformation polymorphism (SSCP) analysis for exons $7(\mathrm{~A})$ and $8(\mathrm{~B})$ of $p 53$ gene on matched normal-tumor (N-T) samples. The differences in the electrophoretic profile of the tumor samples, compared with the respective normal ones are marked by arrows.

observed in 14 out of 21 informative samples (67\%; Fig. 3b). Eight of these cases (57\%) were accompanied by $p 53$ point mutations in the remaining allele (Table 1). Because the immunohistochemical (IHC) status of p53 was highly correlated with sequence analysis $(p=0.004)$ and the number of informative specimens at the $p 53$ locus was rather low, in the following associations we considered p53 IHC positivity as an indicator of $p 53$ gene alterations.

MDM2 STATus. Overexpression of MDM2 (P) was found in 57 out of 85 informative cases $(68 \%)$. IHC positivity with SMP14 antibody was in concordance with the results ob- 


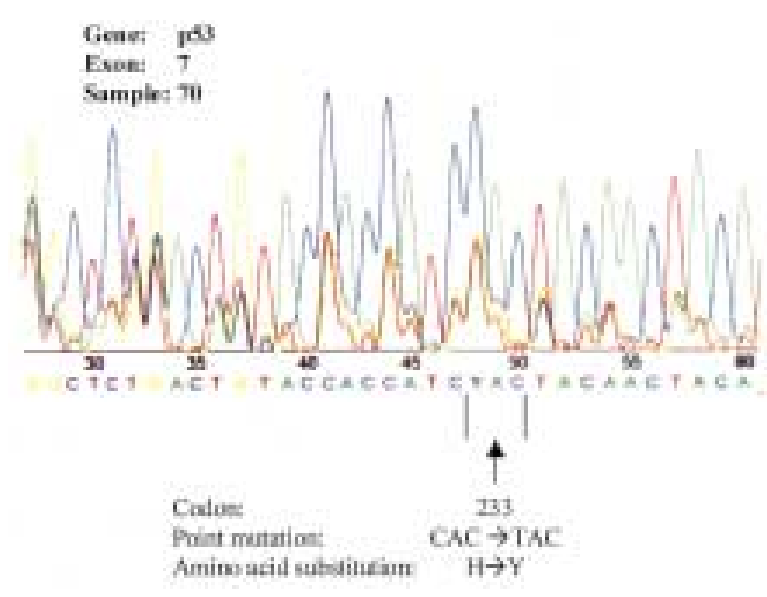

Fig. 5. Representative automated sequencing in a squamous cell lung carcinoma (case 70) with single strand conformation polymorphism (SSCP) mobility shifts in exon 7. The position of the $p 53$ mutation is located at codon 233 and changes CAC $(\mathrm{H})$ to TAC $(\mathrm{Y})$.

tained with the 1B10 MDM2 antibody employed in our previous study (24). MDM2 immunoreactivity was not related to any clinicopathological features of the patients (Table 2, Fig. 2b). The MDM2 mRNA levels were examined in 68 normal and tumor paired samples by a semiquantitative multiplex RT-PCR assay (Table 1). MDM2 mRNA was detected in all normal and tumor specimens. However, the analysis revealed in 43 out of 68 informative cases $(63 \%)$ significantly higher levels of MDM2 mRNA in the tumors, compared with the corresponding normal tissues (Table 1, Fig. 6). The tumor/normal $(\mathrm{T} / \mathrm{N})$ ratio ranged from 0.8-1.2 for normal MDM2 mRNA level (normal expression, NE) and 2-6.5 for high levels of MDM2 mRNA (overexpression, OE). A highly significant association was found between MDM2 immunohistochemical positivity and increased MDM2 mRNA levels [IHC(P)/ mRNA(OE): $41 / 43$ (95\%) vs. IHC(P)/mRNA (NE): $7 / 25(28 \%), p=10^{-8}$ by Pearson's Chisquare test].

\section{Analysis of Proliferative Activity}

RELATIONSHIP WITH CLINICOPATHOLOGICAL PARAMETERS. In the present study, proliferative activity was reflected by the PI, a well established biological marker that quantitatively estimates the growth of neoplasms. It was assessed with MIB-1, the most reliable antibody for estimating growth fraction by immunohistochemistry $(46,47)$. The percentages of cells positive for Ki-67 antigen (80 informative cases) in the cancerous areas ranged from $4.6 \%$ to $70.4 \%$ with a mean value $33.54 \pm 11.05$ (Fig. 2c). Statistical analysis demonstrated that PI was significantly higher in SqCs $(p<0.001$ by Kruskal-Wallis; Table 3; and $p<0.001$ by ANOVA; mean difference (MD): $-10.233 ; 95 \%$ confidence interval (CI): $-14.786,-5.681)$ and smokers $(p=0.041$ by Kruskal-Wallis, Table 3; and $p=0.044$ by ANOVA; MD: 6.95, 95\% CI: $0.19,13.71)$.

RELATIONSHIP WITH EACH ELEMENT OF THE pRb/MDM2/p53 NETWORK. The patients with abnormal expression of each examined mole-

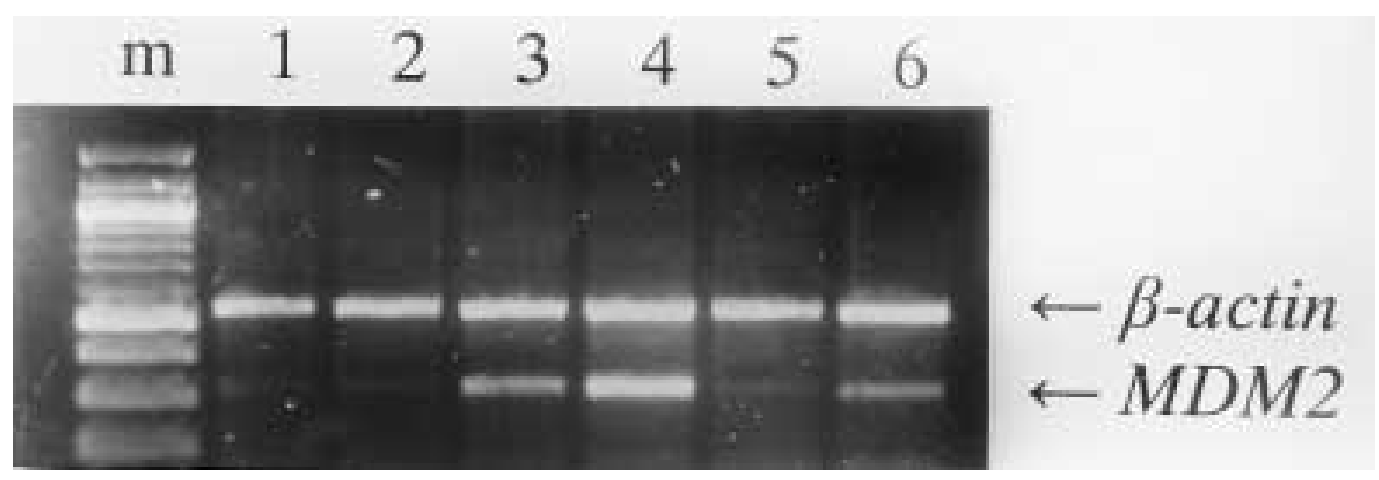

Fig. 6. Representative results of the multiplex reverse transcription polymerase chain reaction (RT-PCR) assay (see Methods) employed in order to evaluate the levels of MDM2 mRNA. m: l00bp DNA ladder; 1-2: Matched normal-tumor case (sample 8) with normal MDM2 mRNA expression; 3-4 and 5-6: Matched normal-tumor cases (sample 9 and 10, respectively) with MDM2 mRNA overexpression. 
cule (pRb: Ab or p53: P or MDM2: P) displayed a significantly higher PI than the cases with normal status (Table 2, $p=0.003$; MD: 7.25, 95\% CI: $2.46,12.03$ for pRb; $p=0.002$, MD: $7.47,95 \%$ CI: $2.75,12.18$ for $\mathrm{p} 53$; and $p=0.004$; MD: 7.36, 95\% CI: 2.38, 12.32 for MDM2, by ANOVA).

\section{Apoptotic Index (AI)}

RELATIONSHIP WITH PI AND CLINICOPATHOLOGICAL PARAMETERS. AI ranged from $0.08 \%$ to $10.67 \%$, with a mean value $1.771 \pm 1.863$ (72 informative cases, Fig. 7). No association between AI and PI was observed by linear regression analysis. Furthermore, apoptosis was not associated with any of the clinicopathological parameters of the patients (Table 3).

RELATIONSHIP WITH EACH ELEMENT OF THE p53/MDM2/pRb NETWORK. AI was significantly reduced when deregulated expression of each examined molecule was observed (pRb: Ab or p53: P or MDM2: P Table 2); [ $p=0.005, \mathrm{MD}$ : $-0.588,95 \% \mathrm{CI}:-0.988,-0.187$ for $\mathrm{pRB} ; p=$ 0.031, MD: -0.459 , 95\% CI: $-0.873,-0.004$ for $\mathrm{p} 53$; and $p=0.031$, MD: $-0.476,95 \% \mathrm{CI}$ : $-0.907,-0.004$ for MDM2, by ANOVA].

\section{Ploidy Status}

RELATIONSHIP WITH PI, AI AND CLINICOPATHOLOGICAL PARAMETERS. Forty-six of the 80 informative cases $(58 \%)$ were evaluated as aneuploid

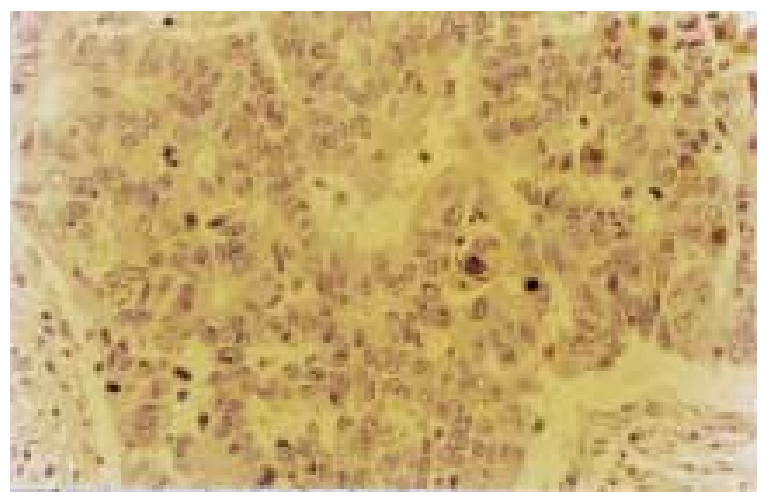

Fig. 7. Lung adenocarcinoma (case 5) with high apoptotic index $(6.3 \%)$. Tdt-mediated dUTP Nick End Labeling assay (TUNEL) (3, $3^{\prime}$-diaminobenzidine tetrahydrochloride $\mathrm{DAB}$ as chromogen, see Methods) and hematoxylin counterstain $(\times 400)$.
(Fig. 8). The aneuploid tumors exhibited significantly higher PI values and decreased AI than the diploid ones $(p=0.003, \mathrm{MD}: 7.41$, 95\% CI: 2.52, 12.30 for PI; and $p=0.030, \mathrm{MD}$ : $-0.484,95 \%$ CI: $-0.920,-0.005$ for $\log$ AI by ANOVA). Aneuploidy was associated with advanced stages of the disease [stage II and III vs. stage I: $33 / 47(70 \%)$ vs. $13 / 32(41 \%), p=0.031$ by Pearson's Chi-square test, Table 3 ; and $p=$ 0.049 , odds ratio: $3.297(1.293,12.100)$ for stage II; and $p=0.021$, odds ratio: 3.956 $(1.058,10.276)$ for stage III in relation to stage I, by logistic regression analysis] and lymph node metastases [32/43 (74\%) vs. 14/36 (39\%), $p=0.003$ by Pearson's Chi-square, Table 3; and $p=0.002$, odds ratio: $4.571(1.754,11.919)$ by logistic regression analysis].

RELATIONSHIP WITH EACH ELEMENT OF THE p53/MDM2/pRb NETWORK. Aberrant expression of pRb, p53 and MDM2 overexpression, independently, were significantly correlated with aneuploidy (Table 2); [ $p=0.036$, odds ratio: $2.778(1.068,7.228)$ for $\mathrm{pRb} ; p=0.039$, odds ratio: $2.618(1.047,6.540)$ for $p 53$; and $p=0.0006$, odds ratio: $6.017(2.170,16.678)$ for MDM2, by logistic regression analysis].

\section{Expression Patterns of p53, MDM2 and $p R b$}

EXPRESSION PATTERNS AND CORRELATION WITH CLINICOPATHOLOGICAL PARAMETERS. We observed 8 out of the 9 theoretically expected patterns (Table 2). Due to the small number of cases in each pattern, we arranged the tumors into four groups according to the alterations detected $(0,1,2$, and 3 alterations). The pRb(Ab)/p53(P)/ MDM2(P) immunoprofile was the most frequent one with 23 out of 85 informative cases (27\%; Table 2). It was also the most common among histological subtypes, carcinomas with lymph node disease and patients with smoking history (Table 2). Statistical analysis based on multinomial-logit model formulation revealed no significant correlations among the four groups and the clinicopathological parameters of the patients.

RELATIONSHIP WITH PI, AI AND PLOIDY STATUS. The patients that demonstrated an immunophenotype with three alterations, displayed a significantly increased PI and reduced AI, compared with those with no defects (Table 4, Figs. 9A, B). Moreover, PI was significantly lower in 

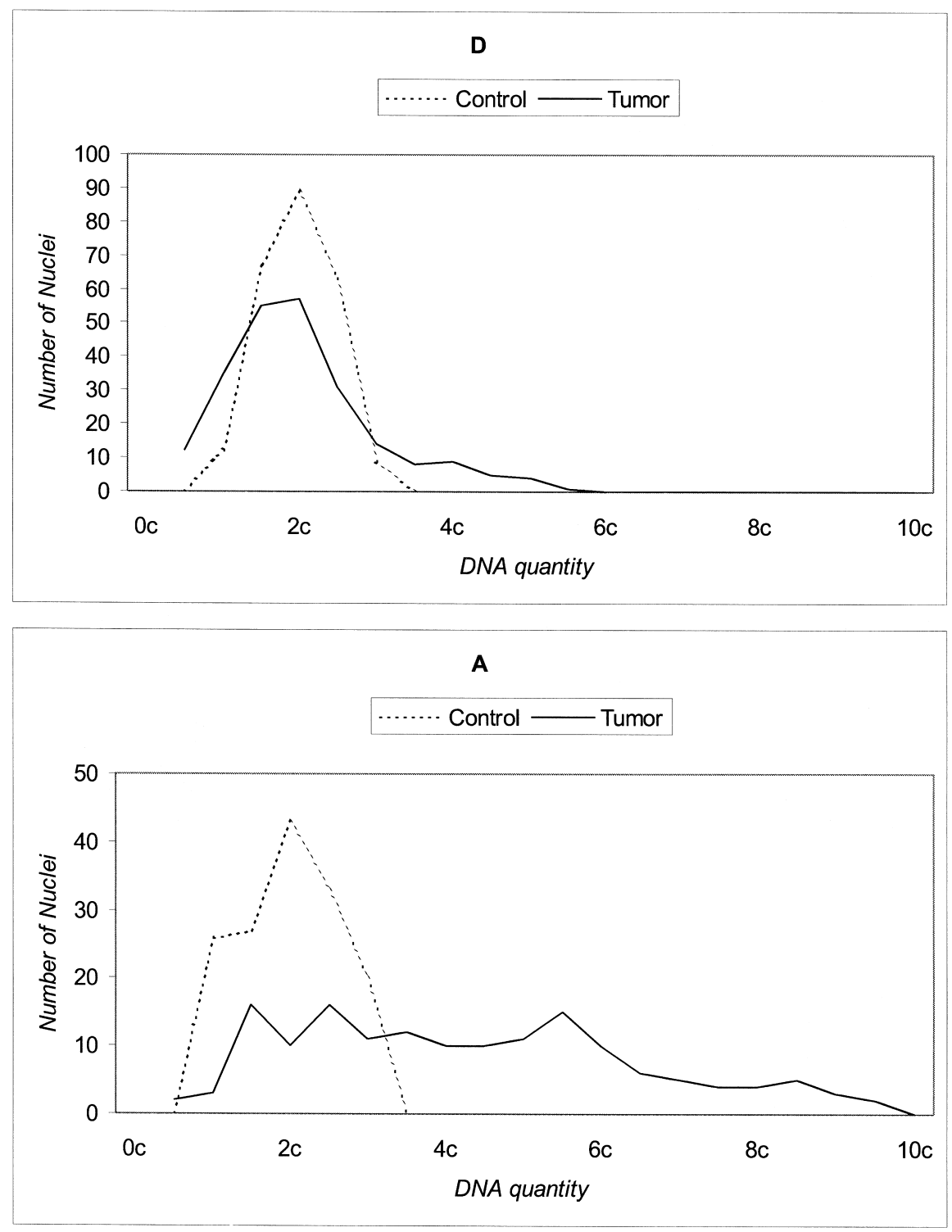

Fig. 8. Representative diagrams presenting the ploidy status of tumor samples (see Methods). D: diploid tumor (case 13), A: aneuploid tumor (case 14).

the cases with one or two alterations, than those with three; whereas, AI was statistically decreased in the samples with one or two abnormalities, than those with none (Table 4, Fig. 9A, B). Notably, the PI/AI ratio obtained the lowest value (15.18 \pm 9.62 , calculated using the values in Table 1) in the cases with the normal phenotype; whereas, the samples with the full abnormal phenotype received the highest PI/AI score [63.23 (15.8 + 48.05); Table 4, Fig. 9C]. As far as ploidy status was concerned, logistic regression analysis indicated that aneuploidy was associated only with the aberrant immunoprofile [pRb(Ab)/ p53(P)/MDM2(P); Table 4].

\section{Survival Analysis}

The Kaplan-Meier methodology was used to estimate the impact of each parameter examined on the patients survival status. During the study (follow-up duration up to 67 months) we observed 38 failures and 45 censored cases. The median survival was 40 months. Differences among survival curves were examined using the log-rank test. The analysis indicated a significant association among poor patient outcome, aneuploidy $(p=0.014)$, stage $(p=$ $0.003)$ and lymph node invasion $(p<0.001$; Table 5). 

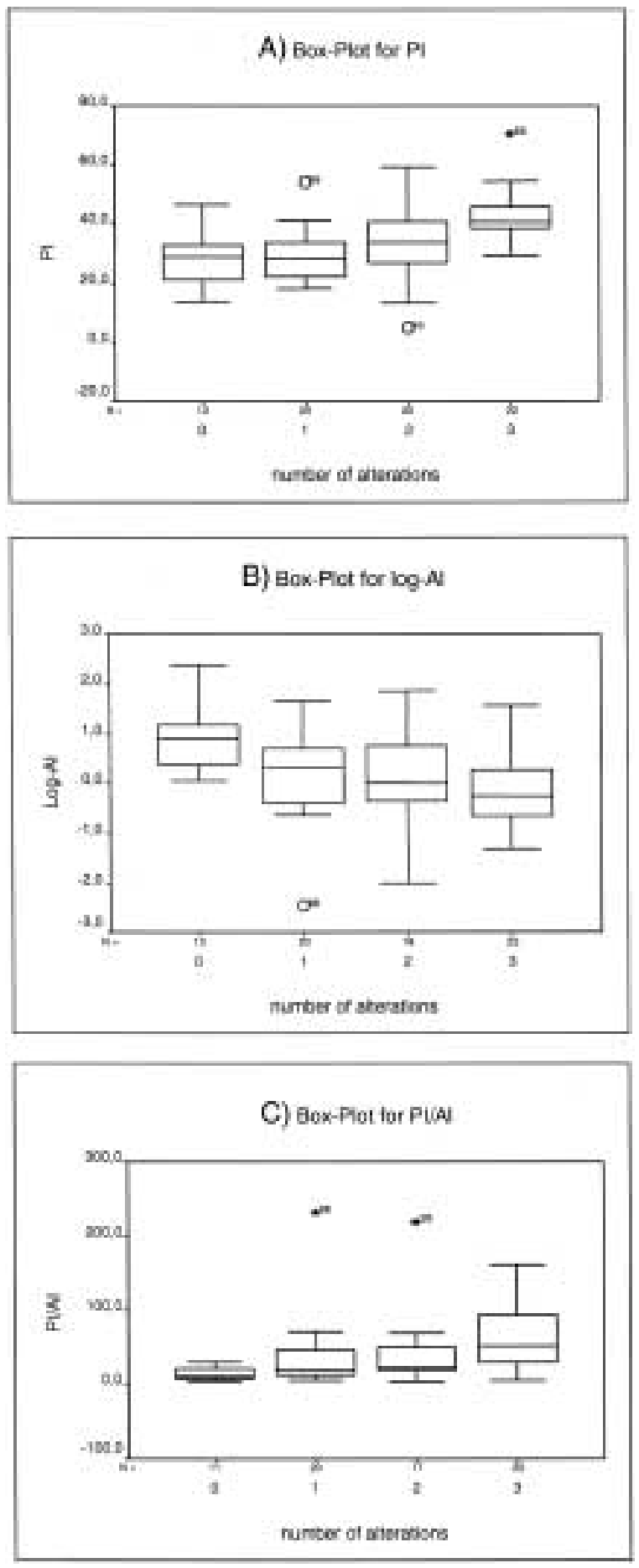

Fig. 9. Box-plots represent the proliferation index (PI) (A) apoptotic index (AI) (B) and the PI/AI ratio $(C)$ of the tumor groups with $0,1,2$ and 3 alterations of the $\mathrm{pRb} / \mathrm{p} 53 / \mathrm{MDM} 2$ network.

\section{Discussion}

The balance between the process of proliferation and programmed cell death is required for homeostasis in any cell population. Deregula- tion of this balance, either by increased proliferation and/or decreased programmed cell death, can lead to neoplasia (35). The pRb and p53 proteins play important roles in controlling both sides of this equilibrium. Recently, it was shown that their ability to regulate the apoptotic procedure is mediated via the MDM2 protein, which interacts directly with both $\mathrm{pRb}$ and p 53 (13). The first part of our study examines the status of these cell cycle regulatory molecules and their relationship with the kinetic parameters of proliferation and apoptosis in a series of 87 NSCLCs. To the best of our knowledge, this information in NSCLCs has not been addressed before.

Abnormal expression of $\mathrm{pRb}(\mathrm{Ab})$ and overexpression of p53 (P) and MDM2 (P) proteins was detected in $39 \%, 57 \%$ and $68 \%$ of the carcinomas, respectively. The percentages for pRb and p53 are comparable with those reported $(48,49)$. As for MDM2, by reviewing the world literature, we found, besides our previous works (22-24), only two other immunohistochemical studies in lung carcinomas $(50,25)$. The results among the three groups differed considerably, although Marchetti et al. (50) and Higashiyama et al. (25) employed the same anti-MDM2 antibody. These differences may be due to technical parameters of the assays and/or criteria of positivity applied by the authors. In the present report, immunohistochemical positivity of p53 and MDM2 reflected deregulation of their expression, since a very strong correlation with $p 53$ gene alterations $(p=0.004)$ and

\begin{tabular}{|c|c|c|}
\hline & \multicolumn{2}{|c|}{ Log-Rank test } \\
\hline & Statistic & $p$ \\
\hline $\mathrm{pRb}$ & 1.665 & 0.197 \\
\hline p53 & 0.594 & 0.441 \\
\hline MDM2 & 2.981 & 0.084 \\
\hline Proliferation Index & -0.697 & 0.321 \\
\hline Apoptotic Index & -2.440 & 0.833 \\
\hline Ploidy Status & 6.045 & 0.014 \\
\hline Smoking History & 0.232 & 0.630 \\
\hline Histology & 4.585 & 0.101 \\
\hline Lymph Node invasion & 23.547 & $<0.001$ \\
\hline Stage & 11.406 & 0.003 \\
\hline
\end{tabular}


increased MDM2 mRNA levels $\left(p=10^{-8}\right)$, respectively, was observed.

The data from the LOH study at the $p 53$ locus were not taken into consideration in our analysis, due to the high percentage of homozygous (non-informative) samples. However, it should be mentioned that $57 \%$ of the cases with $\mathrm{LOH}$ were accompanied with point mutations in the remaining $p 53$ allele, a finding that is in keeping with the "two-hit" hypothesis of oncosuppressor gene inactivation proposed by Knudson (51). The levels of MDM2 mRNA were examined with a sensitive multiplex RT-PCR assay using as the target sequence a conservative area of MDM2 (see "Material and Methods" section). This area lies near the center of the molecule (131-238aa) and includes the nuclear localization and export signals that are necessary for nucleo-cytoplasmic shuttling of MDM2 (42). By examining this region, we excluded the possibility of false-negative results due to alternative splice variants of $M D M 2$ with truncated the $-\mathrm{NH} 2$ or $-\mathrm{COOH}$ terminal portion of the protein (16). As MDM2 immunohistochemical analysis was performed with an antibody directed against the above region of the molecule (154-167aa) and high concordance with increased MDM2 mRNA levels was observed, we assume that at least one of the known MDM2 isoforms, shown to exist in lung carcinomas, is overexpressed in this series (23). It is noteworthy that in nine cases a discordance between MDM2 protein expression and MDM2 mRNA analysis was found (Table 1). This incompatibility in the seven tumors with MDM2 staining and normal mRNA levels may be due to enhanced MDM2 mRNA translation (52); whereas, in the two cases with high MDM2 mRNA levels and lack of protein expression it may be attributed either to technical drawbacks or post-translational events, such as targeted-degradation by $\mathrm{pl} 4^{\mathrm{ARF}}(53,54)$. At this point, it should be mentioned that we and others have shown that MDM2 gene amplification is a very rare phenomenon in lung carcinomas $(22,23,25,49)$. As far as $p R b$ is concerned, immunohistochemistry has been proposed to be the most sensitive method for evaluating $R B 1$ gene inactivation (55), because it examines the protein at a single-cell level. and the large size of the gene (27 exons fused in a $4.7 \mathrm{~Kb}$ transcript) makes sequence analysis a difficult procedure. However, in a portion of our samples, we performed an allelic imbalance analysis of $R B 1$ using the internal chromosomal marker D13S153 and correlated the findings with the immunohistochemical profile of $\mathrm{pRb}$. Correlation between allele loss and aberrant pRb expression was noticed only in $30 \%$ of the cases examined. This puzzling inconsistency has also been observed by others in lung $(55,56)$, breast $(57)$ and bladder $(58)$ carcinomas, thus, raising some doubt as to the significance of $\mathrm{LOH}$ in such tumors. One possible explanation for this finding is that minor deletion within the aforementioned locus, which lies within the large intron downstream of exon 2, would result in $\mathrm{LOH}$, but leave the coding regions intact. In addition, unmasking of a recessive mutation by allele loss cannot be excluded, thus, providing another mechanism behind $R B 1$ inactivation in NSCLCs. If the later hypothesis is proven, then the frequency of $R B 1$ inactivation is higher than that estimated by IHC.

The comprehensive analysis of the three cell cycle regulatory molecules revealed 8 of the 9 theoretically expected patterns (Table 2). Concurrent alterations in all three proteins was the most frequent pattern and represented approximately $27 \%$ of the cases, followed by the $\mathrm{pRb}(\mathrm{No}) / \mathrm{p} 53(\mathrm{~N}) / \mathrm{MDM} 2(\mathrm{P})$ and $\mathrm{pRb}(\mathrm{No}) /$ p53(P)/MDM2(P) profiles, which comprised $18 \%$ and $17 \%$ of the patients, respectively. The fourth most common pattern, with $15 \%$ of the tumors, did not demonstrate any immunohistochemical alterations in the proteins examined, although, in three circumstances, $\mathrm{LOH}$ at the $p 53$ locus was noticed (cases 54, 62 and 66). This latter finding should be kept under consideration since Venkatachalam et al. recently reported that reduction in p53 levels may be sufficient to promote tumorigenesis (59). In the present extended series of NSCLCs, the relationship among the patients' clinicopathological parameters and the various immunoprofiles did not demonstrate any significant correlation confirming our previous findings (24). However, the high frequency of multiple alterations (two and three molecules affected, 44\%), along with the absence of correlation with clinical stage (Table 2), suggest that deregulation of the $\mathrm{pRb} / \mathrm{p} 53 / \mathrm{MDM} 2$ pathway may be a relatively early event in the development and progression of some NSCLCs.

Examining the kinetic parameters of the tumors in association with the various immunophenotypes, we observed that the (PI/ AI) ratio obtained its highest mean value 
$(\mathrm{PI} / \mathrm{AI}=63.23)$ in the group of carcinomas with simultaneous alterations in all three elements of the network; whereas, in the tumors with the normal phenotype it received the lowest one (PI/AR $=15.18 ; p=0.004$; Table 4; Fig. 9C). Moreover, the former pattern [pRb(Ab)/ p53(P)/MDM2(P)] acquired the highest PI $(p<0.001)$ and the lowest AI $(p=0.001)$ scores (Tables 2 and 4; Figs. 9A, $B)$. Together, these findings suggest that coincidental deregulated expression of all members of the pRb/p53/ MDM2 network confers an additive effect on tumor growth. Therefore, on the one end of this scheme, the cancerous cell retains the trimeric pathway intact, thus, pRb controls the activities of the E2F/DP transcription factor family (6) and protects wt p53 from MDM2-targeted degradation (13). Consequently, depending on the cellular context, such as excess activity of cellular oncoproteins (2), wt p53 is capable of promoting either cell cycle arrest or inducing apoptosis, hence, maintaining a relatively low PI/AI ratio. On the other end of this hypothetical scenario, the tumor will have a complete growth advantage. Because p53 protein is mutated, the MDM2 protein is overexpressed and free from the surveillance of $\mathrm{pRb}$ and, thus, is able to exert its tumorigenic effects (13-15) and pRb suppression on the E2F/DP family will be relieved (6). Furthermore, there is increasing evidence that mutations not only eliminate the suppressor activity of the wt p53 protein, but, may also gain function and convert it into an oncogene (60-63). The mechanisms proposed to underlie this positive dominant effect of mutant (mt) p53 include anomalous transcriptional activity (64) or, as we will discuss later, enhancement of genomic instability $(65,32)$. Relative to the first, $\mathrm{mt}$ p 53 proteins have been shown in transient transfection assays, to transactivate the proliferating cell nuclear antigen (PCNA) gene, which encodes a 36kDa nuclear polypeptide that is an auxiliary protein for DNA polymerase $\delta$ (64). This functional association between $\mathrm{mt}$ p 53 and a cell proliferating gene, like PCNA, may possibly represent one of the processes that reside behind the positive correlation between p53 staining and increased PI observed in this $(p=0.001$, Table 2$)$ and other studies in NSCLCs (66-68). Nevertheless, there are reports that do not show such an association (69-71).

Another interesting finding was that the groups of carcinomas with impaired expres- sion of one or two molecules attained PI/AI ratios values clustered in a narrow range from $39.22(15.18+24.05$, Table 4$)$ to $41.98(15.18+$ 26.80, Table 4), which is placed in the middle of the scores exhibited by the normal and full abnormal phenotypes. (Table 4, Fig. 9C). Further analysis demonstrated that these tumors had significantly lower AI, but similar PI values, compared with those noticed in the normal pattern (Table 2). This latter observation insinuates that the apoptotic pathway is more susceptible to defects of the network than the cell proliferation machinery. This assumption is in agreement with the recent findings of Hsieh et al., who demonstrated that one of the main activities of the pRb/MDM2/p53 pathway was the protection of the p53 apoptotic function (13). On the contrary, cell proliferation is significantly deranged only when all members of the network are deregulated, suggesting a counterbalance mechanism. This is a rational conclusion when one of the two oncosuppressors is functional, but what happens when both of them are impaired and MDM2 is intact? Although, in the present work, only two cases fell in this category, they obtained the second highest PI scores (Table 2). This is in accordance with the results of Kinoshita et al., who showed that high proliferative activity in p53-positive NSCLCs was further increased when associated with loss of $\mathrm{pRb}$ or p16 expression (67). Therefore, since the remaining $\mathrm{pRb}(\mathrm{Ab}) / \mathrm{p} 53(\mathrm{P})$ cases were included in the full abnormal immunophenotype group, we can presume that deregulated expressions of pRb and p53 act in a synergistic manner on proliferative activity, which is further enhanced by MDM2 overexpression.

The model suggested above might explain aggressive clinical behavior observed in various carcinomas, including NSCLCs with coincident altered status of $\mathrm{pRb}$ and $\mathrm{p} 53$ (72-74) and faster tumor development in $R B 1^{-1-}, p 53^{-1-}$ transgenic mice than in mice deficient only in $R B 1$ or $p 53$ (75), but it also raises several questions. First, what is the role depicted by the transcription factors of the E2F/DP family and, particularly, E2F1 on cell proliferation and apoptosis in the cases with aberrant $\mathrm{pRb}$ expression? There is substantial evidence that E2F1 may act as an oncogene and a potent inducer of apoptosis in vivo (reviewed in 76). Second, how is MDM2 expression triggered in the tumors where its upstream effector, $p 53$, is mutated and why is 
mutant p53 not degraded by MDM2 in these samples $(10,11)$ ? Third, in view of Brown's and associates' recent finding that MDM2 can induce cell cycle arrest (27), which conditions promote its growth-inhibitory functions and which its growth-stimulating ones?

Relative to the first question, it has been shown in transgenic mouse models that, when the pRb family is disrupted, E2Fl expression is deregulated, inducing increased proliferation and p53-mediated apoptosis $(76,77)$, the later probably via $\mathrm{p} 14^{\mathrm{ARF}}(78)$. In these animal models, loss of E2F-1 dramatically lessens apoptosis, but does not lead to tumor onset, due to a parallel decrease in proliferation. This suggests that a delicate E2F-1-dictated balance between proliferation and apoptosis occurs (77). Moreover, several studies convincingly demonstrate that the tumor suppressor or oncogenic function of E2F1 is determined in a tissue-specific manner (76). Thus, perhaps under certain conditions, such as the overexpression of the appropriate growth factor/receptor system accompanied by loss of the p53 apoptotic function and overexpression of MDM2 (79), the E2F downstream signals weight in favor of proliferation rather than apoptosis. Similar situations occur in the cases of $c-m y c$ $(80,81)$ and $c$-mos proto-oncogenes (82). Experiments are underway in our laboratory to determine the status of E2F1 in our series of NSCLCs. As for the second question, we and others have shown that certain mutant p53 proteins have the ability to transactivate directly $(83,84)$ or indirectly $(85)$ the MDM2 gene. In addition, Shaulian et al. (86), recently reported a p53-independent mechanism of MDM2 induction by the basic fibroblast growth factor (bFGF). Perhaps such a mechanism could account for MDM2 overexpression in the cases with mutant nonfunctional p53 protein, since expression of bFGF and its receptor has been observed in a significant proportion of NSCLCs (87). Further studies are needed to examine whether similar actions are exerted by other growth factors as well. IHC codetection of MDM2 with mt p53 does not necessarily imply complex formation and eventual degradation. The amount of p53 bound with MDM2 is controlled by various modifications, including phosphorylations, dephosphorylations and acetylations, which may be impaired in the context of a cancerous cell (88), or even the existence of other MDM2-variants that do not possess p53-bind- ing domain (16). Moreover, an additional mechanism, which could prevent the association of the two proteins, is deregulated expression of the molecules necessary for p53MDM2 interaction; such is the case of the p300/CBP protein (89). The recent identification of tumor suppressor-like mutations in the p300 gene in colorectal and gastric carcinomas provides support for such ideas (90). Finally, Brown and associates (27) showed that MDM2 blocks G0/Gl-S transition in nontumor cells; whereas, tumor-derived cells are relatively insensitive to the growth inhibitory effects of MDM2. This discrepancy may be due to genetic defects, which render cancer cells tolerant to MDM2. On the other hand, MDM2 protein(s) in tumors may harbor inactive growth inhibitory domains (ID) as a result of splice variants (16) or mutations. Schlott et al. (91) detected mutations of MDM2 in several cancer samples near ID2.

In the second part of this study, we investigated the relationship between the cellular DNA content (ploidy) of the carcinomas and the expression patterns of the pathway. The full abnormal phenotype was associated significantly with aneuploidy $(p=0.011$ by Kruskal-Wallis, Table 2 and $p=0.002$ by logistic regression analysis, Table 4). A tendency was observed when the expression of two components was altered $(p=0.055$ by logistic regression analysis, Table 4$)$. Interestingly, these findings are in parallel with those concerning the proliferative activity and the apoptotic rate analysis, mentioned above, and support the concept that p53, MDM2 and pRb form a tightly regulated network (13). Furthermore, by comparing the individual associations of each element with the DNA content status and that of the $\mathrm{pRb}(\mathrm{Ab}) / \mathrm{p} 53(\mathrm{P}) /$ MDM2(P) pattern (Tables 2 and 4), we noticed that the latter association with aneuploidy was stronger than that of abnormal $\mathrm{p} 53$ $(p=0.037$ by logistic regression analysis, Table 2$)$ and $\mathrm{pRb}$ staining alone $(p=0.034$ by logistic regression analysis, Table 2$)$, but not from overexpressed MDM2 $(p<0.001$ by logistic regression analysis, Table 2). By further analyzing the relationship of each of the above factors with the ploidy status of the carcinomas, several comments can be made. It is well established that wt p53 is a major checkpoint protein involved in DNA, spindle and centrosome surveillance (92). The failure of such a checkpoint may lead to genomic instability. 


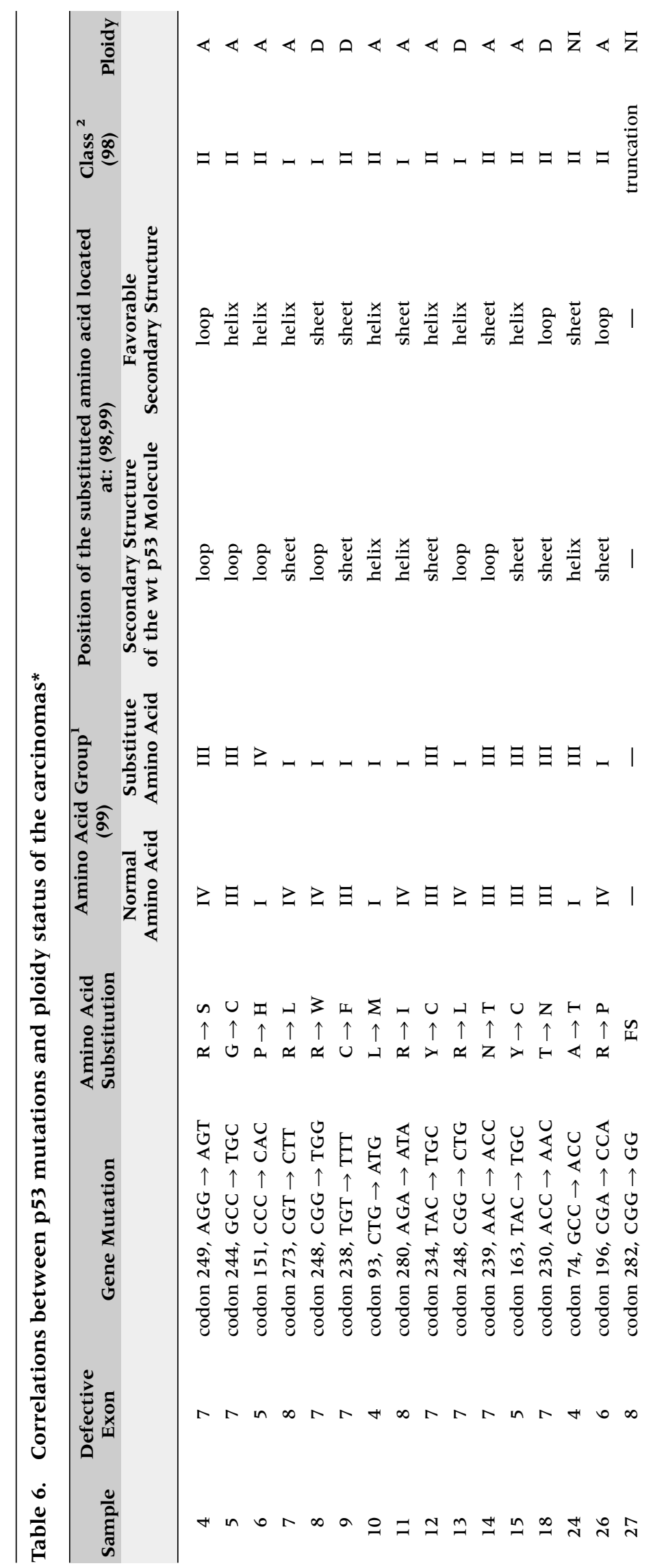




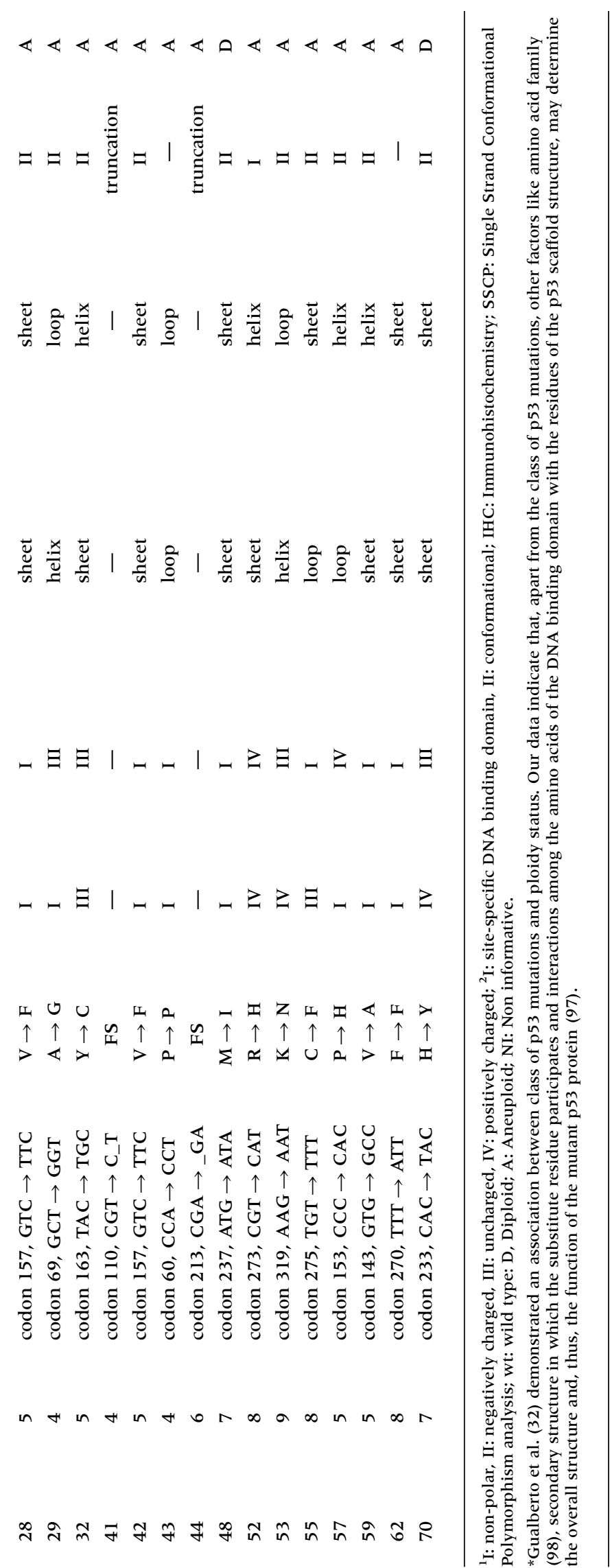


However, when reviewing the literature, we found that the studies that deal with the association between p53 status and DNA content levels in NSCLCs reach controversial conclusions $(45,68,69,93-96)$. Notably, in these reports, p53 was examined only by immunohistochemistry; thus, the exact nature of p53 overexpression was not clear. Recently, Gualberto et al. (32), suggested that the type of $p 53$ mutations may play an important role in defining the ploidy status of a cell by maintaining or disrupting the spindle checkpoint control. Particularly, they showed that certain conformational mutations [class II mutants according to Cho et al. (97)], in fibroblasts from Li-Fraumeni syndrome patients, exhibited a dominant gain of function activity that generated chromosomal instability; whereas mutations in the specific DNA binding domain [class I mutants (97)] and truncations displayed a normal spindle checkpoint response in which cells accumulated with diploid content of DNA (32). In the present study, the majority of $p 53$ mutations, regardless of class, were associated with aneuploidy, although in two cases, mutations at codon 248 (class I mutations) were correlated with diploidy, a finding also demonstrated by Gualberto et al. (32; Table 6). Furthermore, four class II mutations, at codons 238 (case 9), 230 (case 18), 237 (case 48 ) and 233 (case 70), were accompanied with normal DNA content (Table 6). In a late report, Agapova et al. (30) demonstrated that class I mutant Trp248 caused an increase in the frequency of chromosomal breaks and emergence of polyploidy in the human hereditary non-polyposis colon cancer (HNPCC) cell line LIM1215. The findings suggest that, apart from the nature of the $p 53$ mutations, other additional factors may also determine the ability of the cell to monitor correct spindle assemblage. Alterations in other mitotic checkpoint genes, such as mutations in the human homologue of the yeast BUBl gene, support the later view (99). In addition, the recent identification of $14-3-3 \sigma$ protein, a p53 downstream target which is involved in G2/M phase progression, points to the investigation of defects in p53-dependent G2/M effectors in human tumors (100). Besides p53, current data indicate that $\mathrm{pRb}$ plays an essential role in inducing Gl/S cell cycle arrest after DNA damage. This effect is independent from p2 $1^{\text {WAF1/cip } 1}$ activation (36), hinting that simultaneous deregulated expression of p53 and $\mathrm{pRb}$ may lead to premature entry into the $S$ phase. Inappropriate entry into the replication phase results in chromosomal instability, since DNA damage due to extrinsic or intrinsic causes can be efficiently repaired only during the Gl phase. Moreover, shortening of Gl phase may actually cause DNA damage due to failure of the cell to activate enough replication forks, commencement of replication with low levels of nucleotides, or reduced activity of ribonucleotide reductase (RNR) $(1,29)$. Consequently, the importance of p53 and $\mathrm{pRb}$ for maintaining the integrity of the genome, along with the fact that MDM2 seems to play a pivotal role by interacting with both molecules, suggest that overexpression of $\mathrm{pRb}$ could lead to chromosomal instability by over-riding their checkpoint functions.

Finally, the relationship among the kinetic parameters, the ploidy status of the tumors, the clinicopathological parameters, and outcomes of the patients revealed that proliferative activity was significantly associated with histology (higher PI in SqCs than AdCs) and smoking habits. Aneuploidy was also correlated with clinical stage and poor overall survival. A number of studies have examined the utility of measuring the tumor proliferation index as a prognostic marker in patients with NSCLCs with controversial results (99-102). The association found between PI and SqCs has also been reported by two other groups $(46,102)$ and may ascribe the different biological profiles, which characterize SqCs and AdCs of the lung (48). The correlation observed with smoking possibly reflects the association found between smoking and p53, well known target of tobacco derivatives (3). The adverse effect of aneuploidy on patients outcome has been demonstrated by the majority of groups that investigated this topic (103-109) and probably illustrates the cooperative impact of deregulated tumor kinetics, found in the current (see "Results") and other studies (110), and impaired immune surveillance remarked by certain researchers (111).

In conclusion, this study provides evidence that, in a subset of NSCLCs, simultaneous deregulation of the pRb, p53 and MDM2 proteins confers an additive effect on tumor growth and chromosomal instability (Fig. 10). Whether or not this process is applicable in other malignancies, remains to be proven. 


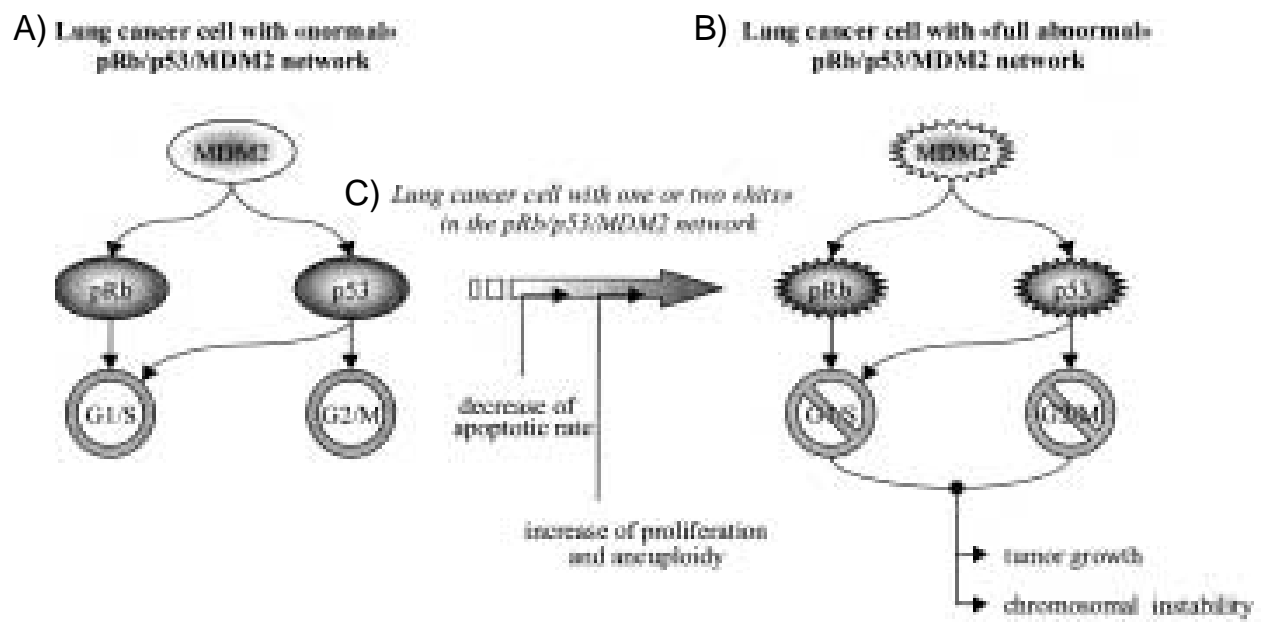

Fig. 10. Hypothetical model describing the effects of the deregulated pRb/p53/MDM2 network on tumor growth and chromosomal stability. Two members of the network play a crucial role in G1/S (p53 and pRb) and G2/M (p53) transition. (A) The tumor cell with intact pRb, p53 and MDM2 has the ability to surveill the G1/S, G2/M and mitosis phases of the cell cycle. (B) The tumor cell with all three molecules impaired exhibits
G1/S, G2/M and M phase checkpoint defects, leading to deregulated tumor growth (uncontrolled proliferation and decreased apoptosis) and to genomic instability. (C) Finally, the tumor cell where intermediate states of $\mathrm{pRb} / \mathrm{p} 53 / \mathrm{MDM} 2$ network dysfunction occur ( 1 or 2 alterations), impairment in cell cycle control also arises. However, cell division mechanism is less sensitive, compared with the programmed cell death procedure (see Discussion).

\section{Acknowledgments}

We thank Dr. P. Kanavaros for helpful criticism on the manuscript. This study was funded by the National Greek Health Committee (KESY) grant A2 $\alpha / 6235 / 30-12-98$ and the Program for Focussed Research Scholarship grant 97 YPER 218. P. Zacharatos is a fellowship recipient of Program for Focused Research Scholarships (YPER 97).

\section{References}

1. Pauvlovich AG, Toczyski DP, Hartwell LH. (1997) When checkpoints fail. Cell 88: 315-321.

2. Serrano M, Lin AW, McCurrach ME, Beach D, Lowe SW. (1997) Oncogenic ras provokes premature cell senescence associated with accumulation of p53 and pl6INK4a. Cell 88: 593602.

3. Greenblatt MS, Bennett WP, Hollstein M, Harris CC. (1995) Mutations in the $p 53$ tumour suppressor gene: Clues to cancer etiology and molecular pathogenesis. Cancer Res. 54: 48554878.

4. Mulligan G, Jacks T. (1998) The retinoblastoma gene family: cousins with overlapping interests. Trends Genet. 14: 223-229.

5. Grana X, Garigga J, Mayol X. (1998) Role of retinoblastoma protein family, pRB, p107 and p130 in the negative control of cell growth. Oncogene 17: 3365-3383.

6. Dyson N. (1998) The regulation of E2F by pRB-family proteins. Genes Dev. 12: 2245-2262.

7. Hengstschlager $M$, Braun $K$, Soucek T, Miloloza A, Hengstschlager-Ottnad E. (1999) Cyclin-dependent kinases at the Gl-S transition of the mammalian cell cycle. Mutat. Res. 436: 1-9.

8. Haas Kogan DA, Kogan SC, Levi D, et al. (1995) Inhibition of apoptosis by the retinoblastoma gene product. EMBO J. 14: 461-472.

9. Prives C, Hall PA. (1999) The p53 pathway. J. Pathol. 187: 112-126.

10. Haupt Y, Maya R, Kazaz A, Oren M. (1997) Mdm2 promotes the rapid degradation of $\mathrm{p} 53$. Nature 387: 296-299.

11. Kubbutat MH, Jones SN, Voysden KH. (1997) Regulation of p53 stability by mdm2. Nature 387: 299-303.

12. Xiao ZX, Chen J, Levine AJ, et al. (1995) Interaction between the retinoblastoma protein and the oncoprotein MDM2. Nature 375: 694-698.

13. Hsieh J-K, Chan FSG, O'Connor DJ, Mittnacht S, Zhong S, Lu X. (1999) Rb regulates the stability and the apoptotic function of p53 via MDM2. Mol. Cell. 3: 181-193.

14. Piette J, Neel H, Marechal V. (1997) Mdm2: keeping p53 under control. Oncogene 15: 10011010.

15. Juven-Gershon T, Oren M. (1999) Mdm2: The Ups and Downs. Mol. Med. 5: 71-83. 
16. Olson DC, Marechal V, Momand J, Chen J, Romocki C, Levine AJ. (1993) Identification and characterization of multiple mdm-2 proteins and mdm-2-p53 protein complexes. Oncogene 8: 2353-2360.

17. Sigalas I, Calvert AH, Anderson JJ, Neal DE, Lunec J. (1996) Alternatively spliced mdm2 transcripts with loss of p53 binding domain sequences: transforming ability and frequent detection in human cancer. Nat. Med. 8: 912-917.

18. Cordon-Cardo C, Latres E, Drobnjak M, et al. (1994) Molecular abnormalities of mdm2 and p53 genes in adult soft tissue sarcomas. Cancer Res. 54: 794-799.

19. Reifenberger G, Liu L, Ichimura K, Schmidt EE, Collins VP. (1993) Amplification and overexpression of the MDM2 gene in a subset of human gliomas without p53 mutations. Cancer Res. 58: 2736-2739.

20. Gudas JM, Nguyen H, Kelin RC, Katayose D, Seth P, Cowan KH. (1995) Differential expression of multiple MDM2 messenger RNAs and proteins in normal and tumorigenic epithelial breast cells. Clin. Cancer Res. 1: 71-80.

21. Lianes P, Orlow I, Zhang ZF, et al. (1994) Altered patterns of MDM2 and TP53 expression in human bladder cancer. J. Natl. Cancer Inst. 86: 1325-1330.

22. Gorgoulis VG, Rassidakis GZ, Karameris AM, et al. (1996) Immunohistochemical and molecular evaluation of the mdm-2 gene product in bronchogenic carcinoma. Mod. Pathol. 9: 544554.

23. Gorgoulis VG, Zoumpourlis V, Rassidakis GZ, et al. (1996) A molecular and immunohistochemical study of the MDM2 protein isoforms and p53 gene product in bronchogenic carcinoma. J. Pathol. 180: 129-137.

24. Gorgoulis VG, Zacharatos P, Kotsinas A, et al. (1998) Alterations of the pl6-pRb pathway and the chromosome locus 9p21-22 in nonsmall-cell lung carcinomas: relationship with p53 and MDM2 protein expression. Am. J. Pathol. 153: 1749-1765.

25. Higashiyama M, Doi O, Kodama $K$, et al. (1997) MDM2 gene amplification and expression in non-small-cell lung cancer: immunohistochemical expression of its protein is a favourable prognostic marker in patients without p53 protein accumulation. Br. J. Cancer 75: 1302-1308.

26. Haines DS. (1997) The mdm2 proto-oncogene. Leuk. Lymphoma 26: 227-238.

27. Brown DR, Thomas CA, Deb SP. (1998) The human oncoprotein MDM2 arrests the cell cycle: elimination of its cell-cycle-inhibitory function induces tumorigenesis. $E M B O \mathrm{~J}$. 9: 2513-2525.

28. Lengauer C, Kinzler KW, Vogelstein B. (1998) Genetic instabilities in human cancers. Nature 396: 643-649.
29. Elledge SJ. (1996) Cell cycle checkpoints: preventing an identity crisis. Science 274: 16641672.

30. Agapova LS, Ilyinskaya GV, Turovets NA, et al. (1996) Chromosome changes caused by alterations of p53 expression. Mutat. Res. 354: 129-138.

31. Waldman T, Lengauer C, Kinzler KW, Vogelstein B. (1996) Uncoupling of S phase and mitosis induced by anticancer agents in cells lacking p21. Nature 381: 713-716.

32. Gualberto A, Aldape K, Kozakiewicz K, Tlsty TD. (1998) An oncogenic form of p53 confers a dominant, gain-of-function phenotype that disrupts spindle checkpoint control. Proc. Natl. Acad. Sci. U.S.A. 95: 5166-5171.

33. Kastan MB, Onyekwere O, Sidransky D, Vogelstein B, Craig RW. (1991) Participation of p53 protein in the cellular response to DNA damage. Cancer Res. 51: 6304-6311.

34. Paules RS, Levedakou EN, Wilson SJ, et al. (1995) Defective G2 checkpoint function in cells from individuals with familial cancer syndromes. Cancer Res. 55: 1763-1773.

35. Martin S, Green D. (1995) Apoptosis and cancer: the failure of controls on cell death and cell survival. Crit. Rec. Oncol. Hematol. 18: 137-153.

36. Harrington EA, Bruce JL, Harlow E, Dyson N. (1998) pRB plays an essential role in cell cycle arrest induced by DNA damage. Proc. Natl. Acad. Sci. U.S.A. 95: 11945-11950.

37. World Health Organization. (1982) The World Health Organization histologic typing of lung tumours. Am. J. Clin. Pathol. 77: 123-136.

38. Kratzke RA, Greatens TM, Rubins JB, et al. (1996) $R b$ and $p 16^{I N K 4 a}$ expression in resected non-small cell lung tumors. Cancer Res. 56: 3415-3420.

39. Davis LG, Dibner MD, Battey JF. (1986) Basic Methods in Molecular Biology. Elsevier Science Publishing Co, Inc., New York, NY.

40. Liloglou T, Maloney P, Xinarianos G, Fear S, Field JK. (2000) Sensitivity and limitations of high throughout fluorescent microsatellite analysis for the detection of allelic imbalance. Application in lung tumours. Int. J. Oncol. 16: 5-14.

41. Bueso-Ramos CE, Yang Y, deLeon E, McCown P, Stass SA, Albitar M. (1993) The human MDM2 oncogene is overexpressed in leukemias. Blood 82: 2617-2623.

42. Freedman DA, Levine AJ. (1998) Nuclear export is required for degradation of endogenous p53 by MDM2 and human papillomavirus E6. Mol. Cell Biol. 18: 7288-7293.

43. Gavrieli Y, Serman Y, Ben Sasson S. (1992) Identification of programmed cell death in situ via specific labelling of nuclear DNA fragmentation. J. Cell Biol. 119: 493-501.

44. Auer GU, Falkmer UG, Zetterberg AD. (1991) Image cytometric nuclear DNA analysis in clin- 
ical tumor material. In Baak JPA (ed.) Kapitel 15 I Manual of quantitative pathology in cancer diagnosis and prognosis. Springer, Heidelberg, Germany. pp. 211-232.

45. Hirano T, Franzen B, Kato H, Ebihara Y, Auer G. (1994) Genesis of squamous cell lung carcinoma. Sequential changes of proliferation, DNA ploidy, and p53 expression. Am. J. Pathol. 144: 296-302.

46. Kawai T, Suzuki M, Kono S, et al. (1994) Proliferating cell nuclear antigen and $\mathrm{Ki}-67$ in lung carcinoma: correlation with DNA flow cytometric analysis. Cancer 74: 2468-2475.

47. Brown DC, Gatter KC. (1990) Monoclonal antibody Ki-67: its use in histopathology (review). Histopathology 17: 489-503.

48. Sekido Y, Fong KM, Minna JD. (1998) Progress in understanding the molecular pathogenesis of human lung cancer. Biochim. Biophys. Acta. 1378: F2 1-F59.

49. Tanaka H, Fujii Y, Hirabayashi H, Miyoshi S, Sakaguchi M, Yoon HE, Matsuda H. (1998) Disruption of the RB pathway and cellproliferative activity in non-small cell lung cancers. Int. J. Cancer (Pred. Oncol.) 79: 111-115.

50. Marchetti A, Buttitta F, Pellegrini S, et al. (1995) $m d m 2$ gene amplification and overexpression in non-small cell lung carcinoma with accumulation of the $\mathrm{p} 53$ protein in the absence of $p 53$ gene mutation. Diagn. Mol. Pathol. 4: 93-97.

51. Knudson AG Jr. (1971) Mutation and cancer: statistical study of retinoblastoma. Proc. Natl. Acad. Sci. U.S.A. 68: 820-823.

52. Landers JE, Cassel SL, George DL. (1997) Translational enhancement of $m d m 2$ oncogene expression in human tumor cells containing a stabilized wild-type p53 protein. Cancer Res. 57: 3562-3568.

53. Pomerantz J, Schreiber-Agus N, Liegeois NJ, et al. (1998) The Ink4a tumor suppressor gene product, p19 Arf, interacts with MDM2 and neutralizes MDM2's inhibition of p53. Cell 92: 713-723.

54. Zhanf Y, Xiong Y, Yarbrough WG. (1998) ARF promotes MDM2 degradation and stabilizes p53: ARF-INK4a locus deletion impairs both the $\mathrm{Rb}$ and $\mathrm{p} 53$ tumor suppression pathways. Cell 92: 725-734.

55. Reissmann PT, Koga H, Takahashi R, et al. (1993) Inactivation of the retinoblastoma susceptibility gene in non-small-cell lung cancer. Oncogene 8: 1913-1919.

56. Betticher DC, White GRM, Vonlanthen S, et al. (1997) Gl control gene status is frequently altered in resectable non-small cell lung cancer. Int. J. Cancer 74: 556-562.

57. Borg A, Zhang QX, Alm P, Olsson H, Sellberg G. (1992) The retinoblastoma gene in breast cancer: allele loss is not correlated with loss of gene protein expression. Cancer Res. 52: 2991-2994.

58. Ishikawa J, Xu H-J, Hu S-X, et al. (1991) Inactivation of the retinoblastoma gene in human bladder and renal cell carcinomas. Cancer Res. 51: 5736-5743.

59. Venkatachalam S, Shi YP, Jones SN, et al. (1998) Retention of wild-type p53 in tumors from p53 heterozygous mice: reduction of p53 dosage can promote cancer formation. EMBO J. 17: 4657-4667.

60. Dittmer D, Pati S, Zambetti GP, et al. (1993) Gain of function mutation in p53. Nat. Genet. 4: 42-46.

61. Hsiao M, Low J, Dorn E, et al. (1994) Gain-offunction mutations of the p53 gene induce lymphohematopoietic metastatic potential and tissue invasiveness. Am. J. Pathol. 145: 702-714.

62. Blandino G, Levine AJ, Oren M. (1999) Mutant p53 gain of function: differential effects of different p53 mutants on resistance of cultured cells to chemotherapy. Oncogene 18: 477-485.

63. Smith PD, Crossland S, Parker G, et al. (1999) Novel p53 mutants selected in BRCA2-associated tumours which dissociate transformation suppression from other wild-type p53 functions. Oncogene 18: 2451-2459.

64. Deb S, Jackson CT, Subler MA, Martin DW. (1992) Modulation of cellular and viral promoters by mutant human p53 proteins found in tumor cells. J. Virol. 66: 6164-6170.

65. Liu PK, Kraus E, Wu TA, Strong LC, Tainsky MA. (1996) Analysis of genomic instability in Li-Fraumeni fibroblasts with germline p53 mutations. Oncogene 12: 2267-2278.

66. Ishida H, Irie K, Itoh T, Furukawa T, Tokunaga O. (1997) The prognostic significance of p53 and $b c l-2$ expression in lung adenocarcinoma and its correlation with Ki-67 growth fraction. Cancer 80: 1034-1045.

67. Kinoshita I, Dosaka-Akita H, Mishina T, et al. (1996) Altered $\mathrm{p} 6^{\mathrm{INK} 4}$ and retinoblastoma protein status in non-small cell lung cancer: Potential synergistic effect with altered p53 protein on proliferative activity. Cancer Res. 56: 5557-5562.

68. Harpole DH Jr, Herndon JE II, Wolfe WG, Iglehart ID, Marks JR. (1995) A prognostic model of recurrence and death in stage I nonsmall cell lung cancer utilizing presentation, histopathology, and oncoprotein expression. Cancer Res. 55: 51-56.

69. Morkve O, Halvorsen OJ, Stangeland L, Gulsvik A, Laerum OD. (1992) Quantitation of biological tumor markers (p53, c-myc, Ki-67 and DNA ploidy) by multiparameter flow cytometry in non-small-cell lung cancer. Int. J. Cancer 52: 851-855.

70. Fontanini G, Bigini D, Vignati S, et al. (1993) p53 expression in non small cell lung cancer: 
clinical and biological correlations. Anticancer Res. 13: 737-742.

71. O'Neill AJ, Staunton MJ, Gaffney EF. (1996) Apoptosis occurs independently of bcl-2 and p53 over-expression in non-small cell lung carcinoma. Histopathology 29: 45-50.

72. Xu HJ, Cagle PT, Hu SX, Li J, Benedict WF. (1996) Altered retinoblastoma and p53 protein status in non-small cell carcinoma of the lung: potential synergistic effects on prognosis. Clin. Cancer Res. 2: 1169-1176.

73. Dosaka-Akita H, Hu SX, Fujino M, et al. (1997) Altered retinoblastoma protein expression in nonsmall cell lung cancer: its synergistic effects with altered ras and p53 protein status on prognosis. Cancer 79: 1329-1337.

74. Cordon-Cardo C, Zhang ZF, Dalbagni G, Drobnjak M, et al. (1997) Cooperative effects of p53 and $\mathrm{pRB}$ alterations in primary superficial bladder tumors. Cancer Res. 57: 1217-1221.

75. Williams BO, Remington L, Albert DM, Mukai S, Bronson RT, Jacks T. (1994) Cooperative tumorigenic effects of germline mutations in $\mathrm{Rb}$ and p53. Nature Genet. 7: 480-484.

76. Yamasaki L. (1999) Balancing proliferation and apoptosis in vivo: the Goldilocks theory and E2F/DP action. Biochim. Biophys. Acta 1423: M9-M15.

77. Pan H, Yin C, Dyson NJ, Harlow E, Yamasaki L, Van Dyke T. (1998) Key roles for E2F1 in signaling p53-dependent apoptosis and in cell division within developing tumors. Mol. Cell 2: 283-292.

78. Bates S, Phillips AC, Clark PA, et al. (1998) P14ARF links the tumor suppressors RB and p53. Nature 395: 124-125.

79. Martin K, Trouche D, Hagemeier C, Sorensen, La Thangue NB, Kouzarides T. (1995) Stimulation of E2F1/DP1 transcriptional activity by MDM2 oncoprotein. Nature 375: 691-694.

80. Bissonnette RP, Echeverri F, Mahboudi A, Green DR. (1992) Apoptotic cell death induced by $\mathrm{c}-M y c$ is inhibited by bcl-2. Nature 359: 552-554.

81. Harrington EA, Bennett MR, Fanidi A, Evan GI. (1994) c-Myc-induced apoptosis in fibroblasts is inhibited by specific cytokines. $E M B O$ J. 13: 3286-3295.

82. Fukasawa K, Vande Woude GF. (1997) Synergy between the Mos/Mitogen-Activated Protein Kinase pathway and loss of p53 function in transformation and chromosome instability. Mol. Cell Biol. 17: 506-518.

83. Gorgoulis VG, Zacharatos PV, Manolis E, et al. (1998) Effects of p53 mutants derived from lung carcinomas on the p53-responsive element (p53RE) of the MDM2 gene. Br. J. Cancer 77: 374-384.

84. Crook T, Marston NJ, Sara EA, Vousden KH. (1994) Trancriptional activation by p53 corre- lates with suppression of growth but not transformation. Cell 265: 1582-1584.

85. Zacharatos PV, Gorgoulis VG, Kotsinas A, et al. (1999) Modulation of wild-type p53 activity by mutant p53 $\mathrm{R} 273 \mathrm{H}$ depends on the p53 responsive element (p53RE). A comparative study between the p53REs of the MDM2, WAF/Cipl and Bax genes in the lung cancer environment. Anticancer Res. 19: 579-588.

86. Shaulian E, Resnitzky D, Shifman O, et al. (1997) Induction of $\mathrm{Mdm} 2$ and enhancement of cell survival by bFGF. Oncogene 15: 27172725.

87. Volm M, Koomagi R, Mattern J, Stammler G. (1997) Prognostic value of basic fibroblast growth factor and its receptor (FGFR-1) in patients with non-small cell lung carcinomas. Eur. J. Cancer 33: 691-693.

88. Prives C. (1998) Signaling to p53: Breaking the MDM2-p53 circuit. Cell 95: 5-8.

89. Grossman SR, Perez M, Kung AL, et al. (1998) p300/MDM2 complexes participate in MDM2mediated p53 degradation. Mol. Cell 2: 405-415.

90. Muraoka M, Konishi M, Kikuchi-Yanoshit R, et al. (1996) p300 gene alteration in colorectal and gastric carcinomas. Oncogene 12: 15651569.

91. Shlott T, Reimer S, Jahns A, et al. (1997) Point mutations and nucleotide insertions in the MDM2 zinc finger structure of human tumors. J. Pathol. 182: 54-61.

92. Fukasawa K, Choi T, Kurivama R, Rulong S, Vande Woude GF. (1996) Abnormal centrosome amplification in the absence of p53. Science 271: 1744-1747.

93. Volm M, Efferth T, Mattern J. (1992) Oncoprotein (c-myc, c-erbB1, c-erbB2, c-fos) and suppressor gene product (p53) expression in squamous cell carcinomas of the lung. Clinical and biological correlations. Anticancer Res. 12: 11-20.

94. Morkve O, Halvorsen OJ, Skjaerven R, Stangeland L, Gulsvik A, Laerum OD. (1993) Prognostic significance of $\mathrm{p} 53$ protein expression and DNA ploidy in surgically treated nonsmall cell lung carcinomas. Anticancer Res. 13: 571-578.

95. Costa A, Silvestrini R, Mochen C, et al. (1996) p53 expression, DNA ploidy and S-phase cell fraction in operable locally advanced nonsmall-cell lung cancer. Br. J. Cancer 73: 914-919.

96. Dalquen P, Moch-H, Feichter G, et al. (1997) DNA aneuploidy, S-phase fraction, nuclear p53 positivity, and survival in non-small-cell lung carcinoma. Virchows Arch. 431: 173-179.

97. Cho Y, Gorina S, Jeffrey PD, Pavletich NP. (1994) Crystal structure of a p53 tumor suppressor-DNA complex: understanding tumorigenic mutations. Science 265: 346-355. 
98. Creighton TE. (1984) Proteins, Structures and Molecular Properties. WH Freeman, New York, NY. pp. 235.

99. Cahill DP, Lengauer C, Yu J, et al. (1998) Mutations of mitotic checkpoint genes in human cancers. Nature 392: 300-303.

100. Hermeking $H$, Lengauer $C$, Polyak $K$, et al. (1997) 14-3-3 sigma is a p53-regulated inhibitor of G2/M progression. Mol. Cell 1: 3-11.

101. Mehdi SA, Etzell JE, Newman NB, et al. (1998) Prognostic significance of Ki-67 immunostaining and symptoms in resected stage I and II nonsmall cell lung cancer. Lung Cancer 20: 99-108.

102. Pujol JL, Simony J, Jolimoy G, et al. (1996) Hypodiploidy, Ki-67 growth fraction and prognosis of surgically resected lung cancers. Br. J. Cancer 74: 964-970.

103. Scaglioti GV, Micela M, Gubetta L, et al. (1993) Prognostic significance of Ki-67 labelling in resected non small cell cancer. Eur. J. Cancer 29A: 363-365.

104. Tungekar MF, Gatter KC, Dunhill MS, Mason DY. (1991) Ki-67 immunostaining and survival in operable lung cancer. Histopathology 19: 545-550.

105. Zimmerman PV, Hawson GA, Bint MH, Parsons PG. (1987) Ploidy as a prognostic determinant in surgically treated lung cancer. Lancet 2: 530-533.
106. Volm M, Mattern J, Muller T, Drings P. (1988) Flow cytometry of epidermoid lung carcinomas: relationship of ploidy and cell cycle phases to survival. A five-year follow up study. Anticancer Res. 8: 105-112.

107. Isobe H, Miyamoto H, Shimizu T, et al. (1990) Prognostic and therapeutic significance of flow cytometric nuclear DNA content in non-small cell lung cancer. Cancer 65: 1391-1395.

108. Miyamoto $H$, Harada $M$, Isobe $H$, et al. (1991) Prognostic value of nuclear DNA content and expression of the ras oncogene product in lung cancer. Cancer Res. 51: 6346-6350.

109. Ogawa J, Tsurumi T, Inoue H, Shohtsu A. (1992) Relationship between tumor DNA ploidy and regional lymph node changes in lung cancer. Cancer 69: 1688-1695.

110. Fontanini G, Pingitore R, Bigini D, et al. (1992) Growth fraction in non-small lung cancer estimated by proliferating cell nuclear antigen and comparison with Ki-67 labeling and DNA flow cytometry data. Am. J. Pathol. 141: 1285-1290.

111. Redondo $M$, Concha A, Oldivela $R$, et al. (1991) Expression of HLA class I and II antigens in bronchogenic carcinomas: its relationship to cellular DNA content and clinicalpathological parameters. Cancer Res. 51: 49484954. 